Rate of clearance of cortisol from the body was accelerated by thyroid hormone either in reduction and conjugation by human liver or in renal clearance of guinea pigs.

Hyperactivity of adrenal cortex in hyperthyroidism, and diminished adrenal activity in myxedema, seem to be an expression of feed back mechanism of anterior pituitary to maintain a constant plasma level of cortisol as suggested previouly by DiRaimondo, Peterson and other investigator. There was some evidence of exhaustion in secretory activity of adrenal cortex in hyperthyroidism due to over doses of ACTH stimulation.

\title{
Morphological and Functional Studies on the Secretory Mechanism of the Thyroid Stimulating Hormone
}

\section{Koji KIDO}

Department of Obstetrics \& Gynecology, Kobe Medical College (Director : Prof. Yasuo Ueda)

On the subject of the secretory mechanism of the thyroid stimulating hormone in the anterior pituitary, there still remains a number of unsolved problems.

To clarify one of the aspects, the author has attempted an investigation of TSH content in the pituitary gland which was assayed by the modified Greenspan method and histochemical studies of the pituitary under the various experimental conditions in female rats.

The results are summarized as follows :

A) Radiothyroidectomized female rats.

1) The anterior pituitary gland showed remarkable hypertrophy after the radiothyroidectomy and TSH content of the pituitary of the radiothyroidectomized rat was as shown in Table 1.

Table 1. TSH Content in the anterior Pituitary after Radiothyroidectomy.

\begin{tabular}{c|c|c}
\hline $\begin{array}{c}\text { Time after } \\
\text { radiothyroidectomy } \\
\text { (days) }\end{array}$ & $\begin{array}{c}\text { No. of } \\
\text { rats }\end{array}$ & $\begin{array}{c}\text { TSH content in } \\
\text { pituitary (J.S.U.) }\end{array}$ \\
\cline { 2 - 3 } normal females & 6 & Pituitary weight (mg) \\
7 & 5 & 0.054 \\
14 & 5 & 0.038 \\
30 & 5 & 0.105 \\
45 & 4 & 0.152 \\
60 & 4 & 0.207 \\
120 & 6 & 0.456 \\
\hline
\end{tabular}

2) On the histochemical observation, the acidophils were distinctly decreased in number for 7 days after the radiothyroidectomy and these were quite difficult to distinguish from the chromophobes after 30 days, whereas the basophils were increased in size and number after the radiothyroidectomy.

Sixty days after the radiothyroidectomy, the thyroidectomy cells appeared, containing coarse, dense granules, ( $\mathrm{T}$ granules) which give an intense reaction with the periodic acid-Schiff reagent for carbohydrate, and at the same time there appeared a few chromophobes with the protoplasm which has an affinity for staining. 
B) Castrated female rats.

1) The anterior pituitary weight had significantly increased after the castration and at the same time, TSH content in the pituitary was markedly decreased. The tendency was particularly noticeable as time elapsed after castration. (Table 2)

Table 2. TSH content in the anterior pituitary after castration.

\begin{tabular}{c|c|c}
\hline $\begin{array}{c}\text { Days after } \\
\text { castration }\end{array}$ & $\begin{array}{c}\text { No. of } \\
\text { rats }\end{array}$ & $\begin{array}{c}\text { TSH content in } \\
\text { pituitary (J.S.U.) }\end{array}$ \\
\cline { 2 - 3 } & Pituitary weight (mg) \\
\hline normal females & 6 & 0.054 \\
14 & 5 & 0.033 \\
21 & 6 & 0.019 \\
28 & 5 & 0.012 \\
\hline
\end{tabular}

2) The finding of histochemical studies were characterized by decreased tendency in number of the basophils (thyrotrophs), containing the granules which were strongly stained by aldehyde-fuchsin after castration, but there was a progressive increase in number and size of the basophils (gonadotrophs). The castration cells were shown to have increased in number in parall with the course of the post-operative period.

C) The female rats with administration of various stetroids during the 2 weeks after castration.

1) The anterior pituitary weight was shown to be the same as in the castration and TSH content of the pituitary was significantly increased with estrogen administration alone and was not influenced by other steroids (Table 3).

Table 3. TSH content in the anterior pituitary with treatment of various steroids during the 2 weeks after castration.

\begin{tabular}{|c|c|c|}
\hline \multirow{2}{*}{ Treatment } & \multirow{2}{*}{$\begin{array}{l}\text { No. of } \\
\text { rats }\end{array}$} & TSH content (J.S.U.) \\
\hline & & pituitary weight (mg) \\
\hline castration only & 5 & 0.033 \\
\hline estradiol benz. $(2.5 \gamma)$ & 4 & 0.065 \\
\hline estradiol benz. ( $1 \mathrm{mg})$ & 4 & 0.060 \\
\hline progesterone $(2.5 \mathrm{mg})$ & 4 & 0.047 \\
\hline testosterone prop. (25mg) & 4 & 0.045 \\
\hline EP Hormone & 6 & 0.063 \\
\hline
\end{tabular}

2) Histochemically, the injections of either estrogen or estrogen with progesterone had inhibited the appearence of castration cells, while in the case of progesterone or androgen injections, no such findings were observed.

From these results, it may be concluded that $\mathrm{T}$ granules and Gomori's granules are considered to be closely related with the secretory mechanism of TSH in the pituitary. Furthermore, among the castrated female rats and rats which had received various steroids, the TSH content in the pituitary was reflected by the thyroid function of rats. 


\title{
向甲状腺ホルモン分泌に関する形態学的

\author{
並びに機能的研究
}

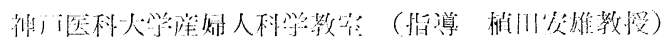

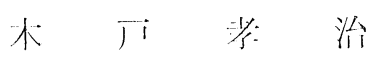

目次

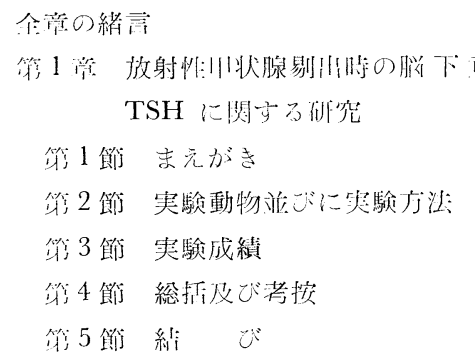

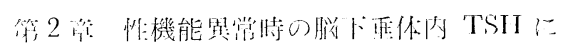

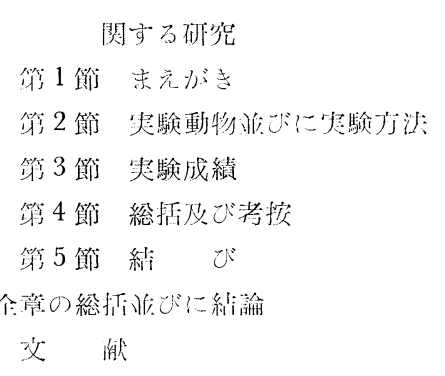

言

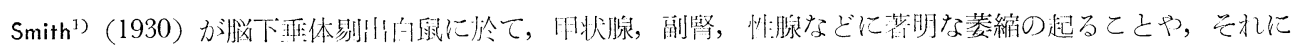

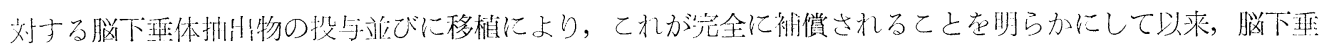

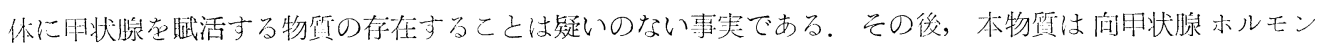
（以下 TSH と略記する）として分離，抽出され，その target organ である甲状腺に対する作用機序につ

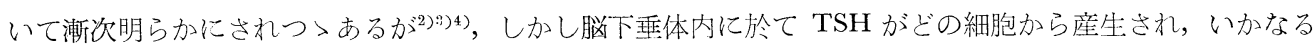

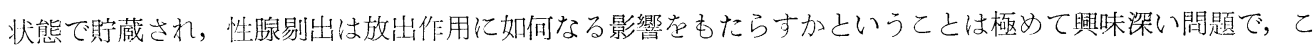
れについて多くの動物実験が行なわれ，種々報告されているにあ拘わらず，未だ一致した見解を得るに至つ ていない.

往来信頼するに足る TSH 検定江がなかつたために，乙の方面の侀究は主として形態学的に行なれれて来

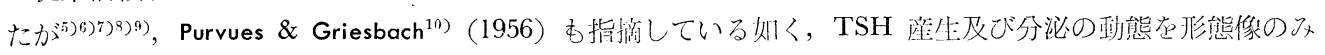
で判断するのは推定の域を脱しない.

最近放射性同位元素の出現によりTSH検定法に屯改良が加えられたが，著者の教室に於てはGreenspan ${ }^{199}$ (1956) の TSH 検定法を検钨して立分信頼しうることを確認している ${ }^{11)}$.

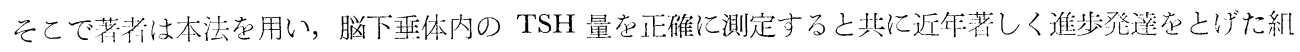

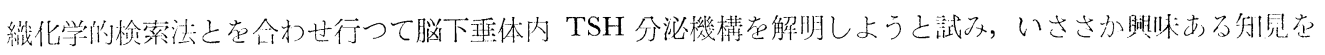
得たので慈に報告する。

\section{第 1 章 甲状腺剔出時の脳下垂体内 TSH に関する研究}

\section{第 1 節 まえがき}

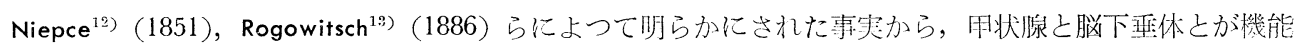

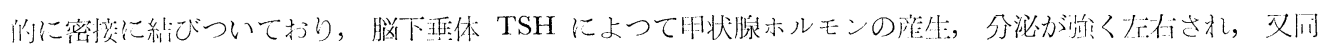

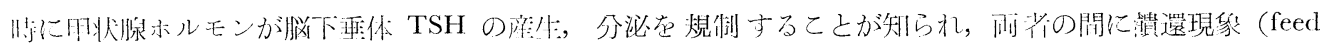


back relation) のあることが, Griesbach et al. ${ }^{14)}$ (1941), Mac Kenzie et al. (1943) ${ }^{15)}$, Astwood et al. ${ }^{16)}$ （1943）らによつて明らかにされた。 こうした TSH そ甲状腺ホルモンの触還型相関は甲状腺機能低下，甲 状腺剔出の際の脳下垂体前葉細胞の変化からも観察されている。しかしながら，その場合に於ける脳下重休 TSH 含有量に関する芫解は必らずしも一致しているとは言い得ず，壯には全く反刘の研究結果が発表され ている.

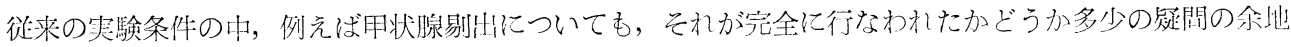
わ゙ある。

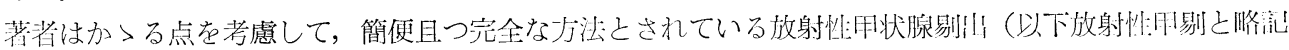

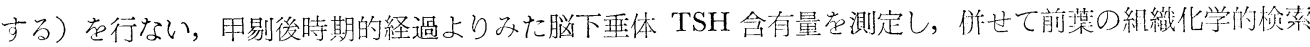
を行ない，脳下垂体内 TSH の動態を把握し，TSH 分泌細胞について㭘索した。

\section{第 2 節 実験動物並びに実験方法}

䒠験動物は環境死可及的に一定とした体重 $100 \mathrm{gm}$ 前後の C 系成熟雌白鼠在用い，オリエンタル闻形们料

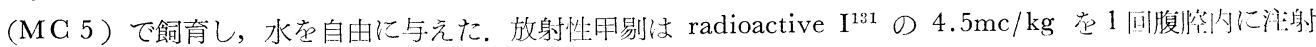
し，その日を甲剔第一日とし，甲剔7，14，30，45，60，120日目に各々屠殺し検索した。

白鼠の脳下垂体剔出方法はエーテル麻酔のもとで開腹し，心臓穿刺により鴧向致死せしめて後，開頭し， 脳下垂体を原形のま〉取り出し，その新鮮重量を torsion balanc で科量した。

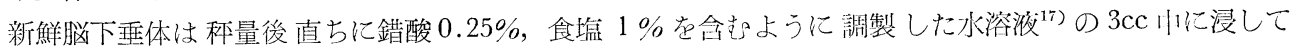


来た粉末を生理的食塩水1 $1 \mathrm{cc}$ 亿功，乙れを材料とした。

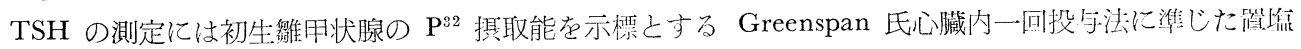

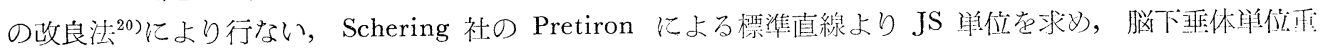
㫫当りの TSH の含有量在算定した.

他方, 脳下垂体前葉の組織学的検索のために一部の実験動物の脳下重体は重量の測定後, 直ちに Susa 氏液又は Bouin 氏液に固定した。

Susa 氏液固定後，脱水操作に移る前に組織のヨード化を行ない，更に $0.25 \%$ 次西硫酸ナトリウム液に投 じて 6〜8 時間放置し，更に水洗し，次いで脱水して型の如くパラフィンに包埋し，4 4 切片として染色を 行つた.

染色は Mallory Azan 染色, PAS 染色, Gomori 氏 aldehyde fuchsin 染色, Wilson 氏染色 ${ }^{21)}$, haematoxylin-eosin 染色を施し，脳下垂体水平断面の最屯㕕い面積をむつ切片を撰び，各前葉細胞の観祭， 算定を行つた。算定方汪は Rasmussen 法 ${ }^{22}$ の変法である井上の方法 ${ }^{22}$ に準じて行つた.

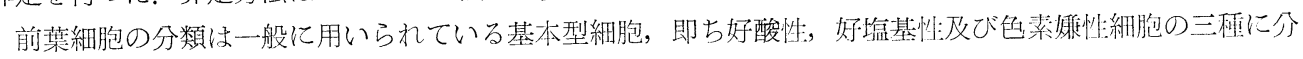
類した.

なお，硝子様変法及び小空胞を有する所謂甲剔細胞や Halmi ${ }^{24)}$ (1952)，Purves \& Griesbach ${ }^{10)}$ (1956) の 提唱する $\mathrm{T}$ 顆粒を有する細胞は好塩基性細胞の範疇に入れた.

\section{第 3 節 実験成績}

\section{(1) 脳下垂体重量}

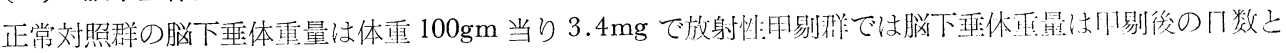

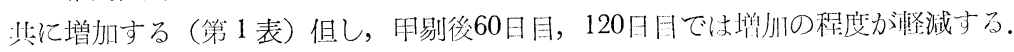

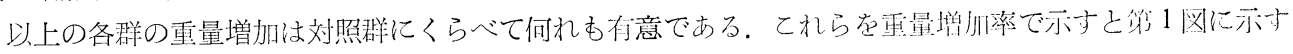
则くであり，甲剔45日では対照群にくらべて100\%以上の增加がみられた。

\section{(2) 脳下垂体 TSH含有量の推移}

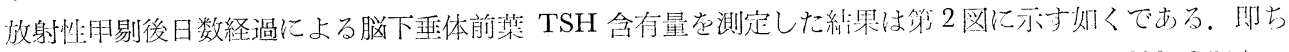

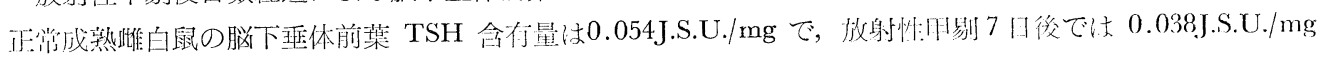


第 1 表 放射性用剔後の体重，脳下垂体重量

\begin{tabular}{|c|c|c|c|c|c|c|c|}
\hline & & 動 & 物 & 数 & $\begin{array}{r}\text { 屠殺 時体重 } \\
\text { (mg) }\end{array}$ & $\begin{array}{r}\text { 脳下垂体重量 } \\
(\mathrm{mg})\end{array}$ & $\frac{\text { 盟下垂体重mg }}{\text { 体重 } 100 \mathrm{mg}}$ \\
\hline \multicolumn{2}{|c|}{ 正常血処置群 } & & 6 & & 153.1 & 5.1 & 3.4 \\
\hline 凡㓫 & 7日 & & 5 & & 152.8 & 7.1 & 4.7 \\
\hline "1 & 14日 & & 5 & & 147.4 & 7.2 & 4.8 \\
\hline " & 30日 & & 5 & & 110.7 & 7.2 & 6.5 \\
\hline "1 & 45 日 & & 4 & & 96.2 & 7.0 & 7.2 \\
\hline " & 60 日 & & 4 & & 93.8 & 6.4 & 6.7 \\
\hline " & 120 月 & & 6 & & 108.1 & 6.5 & 6.1 \\
\hline
\end{tabular}

第 1 図＼cjkstart放射㤬甲剔後の脳下垂体重量增加率



○対照群 ○実験群

で䍀かに減少の傾向をみたが，14日以降は增加の一途を辿り，14日，30日，45日，60日では夫々0.105， 0.152，0.207，0.453J.S.U./mg と增玑し，120日後では 0.681J.S.U./mg となり，正常啡にくらべて約12.6 倍の值を得た。しかし前述の如く放射性甲剔後脳下垂体重量は变化するから，脳下垂体全 TSH 量を計算し てみると7 日後ではや>減少をみるも，旮れ以降14日，30日，45日，60日と増加し，120日では 4.154J.S.U. で正常群の約23.2倍である。

以上の観察加放射性甲剔後に於ける脳下 正休单位重量当りの TSH 含有量立びにTSH 全量汁 7 日目頃化一過性にや>減少するが, 气の後藷しく增加守る（第 2 表，第 2 図）

\section{(3) 脳下垂体前葉の組織学的所見}

(a) 正常成熟白鼠群

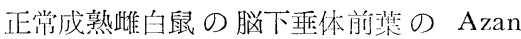
染色標木では, 好酸性細胞は赤染し, Azocarmin, Orange G 亿濃染する極好て微縕 尔顆䊉有し，核は通常门形で，只の大きさ

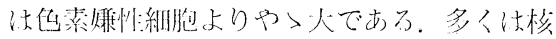

第 2 表 放射性甲剔後の脳下韭体 TSH 量

\begin{tabular}{|c|c|c|c|c|}
\hline & & 動 & 物 数 & $\frac{\mathrm{TSH}}{\text { 脸下臯体 } \mathrm{mg}}$ \\
\hline \multicolumn{2}{|c|}{ 正常皿処置啡 } & & 6 & 0.054 \\
\hline 月1 剔 & 7 & & 5 & 0.038 \\
\hline 11 & 14 П & & 5 & 0.105 \\
\hline "1 & 30 ॠ & & 5 & 0.152 \\
\hline "1 & $45 \Gamma$ & & 4 & 0.207 \\
\hline 11 & 60 & & 4 & 0.453 \\
\hline 11 & 120 & & 6 & 0.681 \\
\hline
\end{tabular}




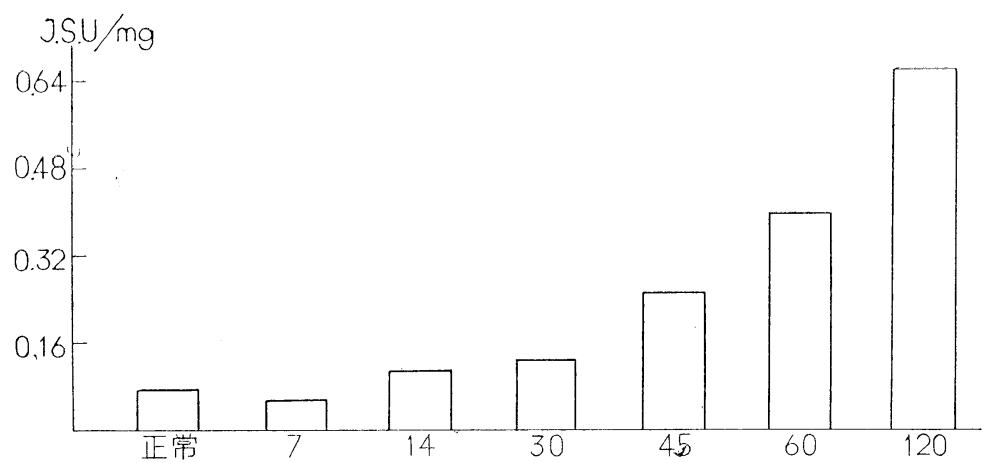

小体が明らかであり，原北啠のAzocarmin 染色性により，濃染性の型と淡染性の二種に分類される，好酸 性細胞の百分比は38.5 1 $1.5 \%$ である。好塩基性細胞は Anilin blue で青染し，円形多角型を示し，大小の 差は著明で，細胞輪廓の不明瞭なあのもある。顆粒も好酸性細胞にくらべて少なく，核は円形で一方に偏し て明るく，核小体も概ね明瞭である．Purves \& Griesbach (1951) の所謂 gonadotrophs は脳下垂体門脈系 に沿うて存在する円形大型の好塩基性細胞で，後述する thyrotrophs にくらべて，その顆粒は PAS 染色 で紫亦色に染り，粗大，且つ濃厚である。一力 thyrotrophs は前葉中心部に好んで位置する多角形の好塩性: 細胞で，その核小体は一般に gonadotrophs よりや〉大で，PAS 染色，Gomori 氏染色で濃染される，そ の細胞百分比は $9.3 \pm 0.74 \%$ であつた，色素伢性細胞は明瞭な染色性顆粓を示さず，好酸性細胞よりや〉小 で，核は円形で明るいものが多く，原形質は余り明らかでない. Wilson 氏染色では thyrotrophs は赤色に gonadotrophs は紫色に染まるが，正常脳下垂体前葉に泛てはその鑑则は必らずしも容易でない.

以上細胞と染色方法に依る色調を表示すれば第 3 表の如くである.

第 3 表 脳下垂体前葉細胞之染色性の関係

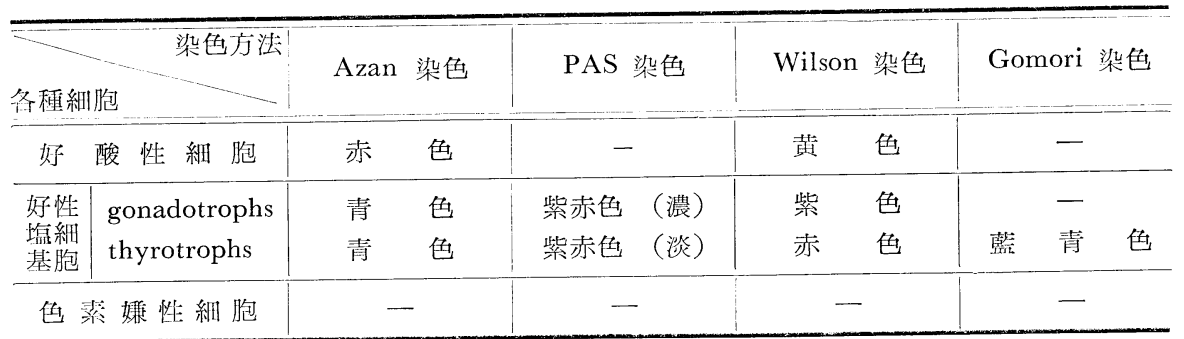

(b) 放射性甲状腺剔古群

i) 放射怅: 目剔後 7 月目

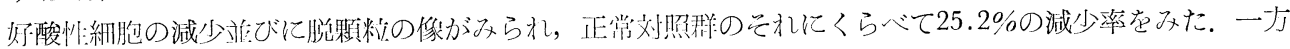

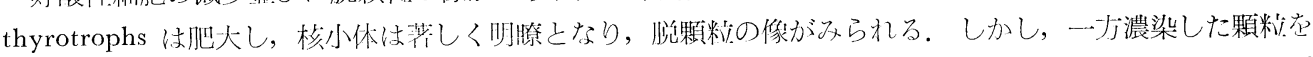

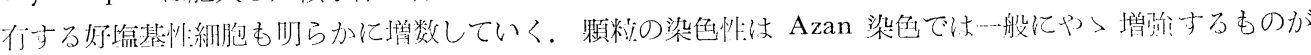

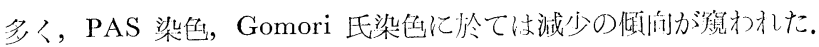

ii）放射州:䟧剔後14币目

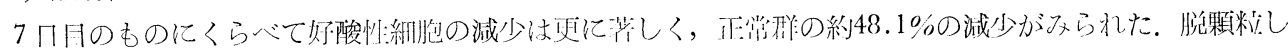

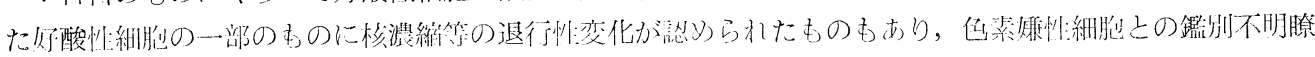


なものが可成り見られた，好塩基性細胞は更に增数，肥大が顕著であるが，原形質の好塩基性顆粒の減少が みられ，微細な空胞を多数含むものが好塩基性細胞の過半数に認められた。，又， anillin blue に均等に可染 される硝子様物犋の出現をみた。しかし, PAS 染色, Gomori 氏染色では硝子様物質は全く可染されない,

iii）放射性甲剔後30日目

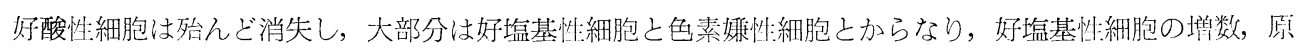

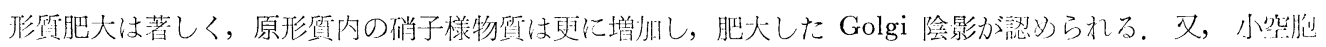

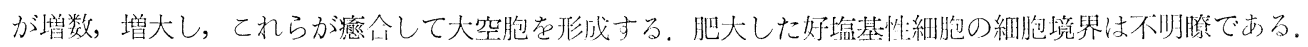

iv）放射性甲剔後 45 日目

好酸性細胞は全く消失し，好塩基性細胞の空胞形成は更に著しくなり，核が周辺部に圧排された所满胴剔 細胞が多数出現している.

v) 放射性甲剔後 60 日目

好塩基性細胞の肥大は最む著明となり, 甲剔細胞は更に增川衣る。PAS 染色, Gomori 氏染色で䍇染さ

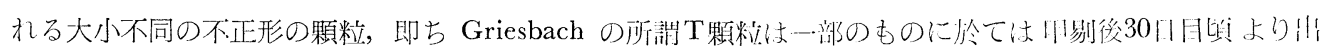

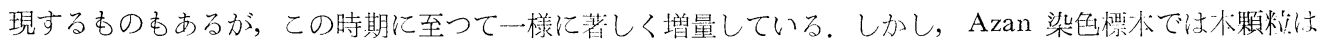
明らかでない，又，好酸性細胞は注ら゙完全に消失している。

vi）放射性甲剔後120日目

一般に好塩基性細胞は甲剔後60日のそれにくらべてや〉萎縮している。原形質の硝子栐物斦，空胞形成な

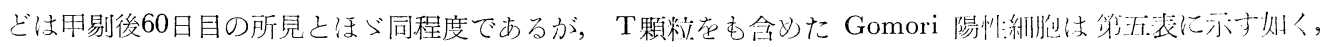
この時期に於てはこの数は最高である。好酸北練胞は全く浔りられなかつた。

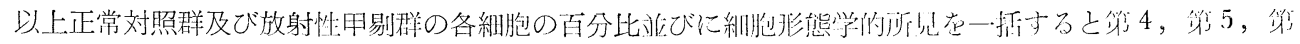
6 表の如くである.

\section{第 4 節 総括及び考按}

実験成績の各事項につき総括し，考察を加えるとととする．

\section{(1) 脳下垂体重量}

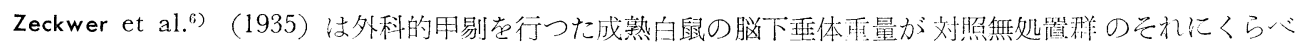

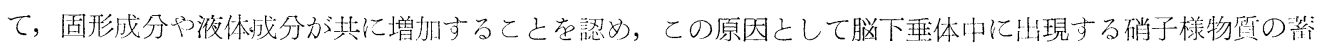

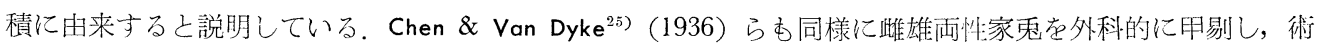
後14日目になると脳下垂体重量は液体成分のみ增加すると述心，又，Turner＆Cupps ${ }^{26)}$ (1940) らは両州成 熟白鼠に於て術後40日を経過する上対照群にくらべて軽度の增加をみたと報告しており，Gordon et al. ${ }^{27}$ （1945）も同様の変化を白鼠に見ている。 Gumbreck ${ }^{28}$ （1957）は単に外科的甲剔のみでは脳下垂体禹量の增 加を認め得ないが，この際同時に去梦在行なうと有意の増加を示す之述へている。文，近年放射性同位元 素をあつてする甲剔が行なわれる様になつたが，Goldberg et al. ${ }^{29}$ （1950）は汒を用いて白鼠の甲剔を行

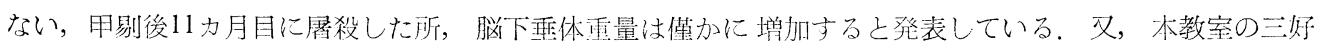

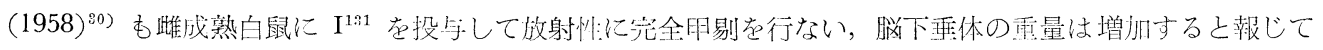
いる. Goldberg，三好ら之同様の放射性:甲剔在行つた私の実験成䋶に於ては，脳下垂体はすでに甲剔後 7 日

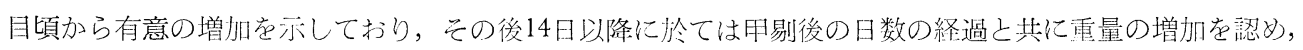

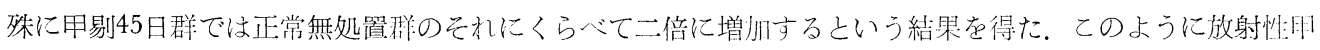
剔によつて脳下重体重量分著明に增加することは近年 Furth et al. (1951,

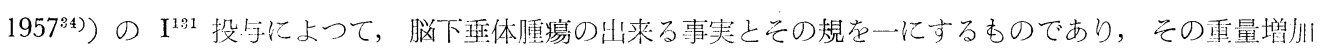
は組織学的所見に照し命わせて，好塩基恻:練胞の增数，細胞原形質の肥大に起因するものと考えられる。

\section{（2）脳下垂体 TSH 含有量に就いて}

Adams (1946) ${ }^{35}$ ) の報告以来, この方面に関する研究は可成りの数に及ぶが，現在なお一定の結論在街て

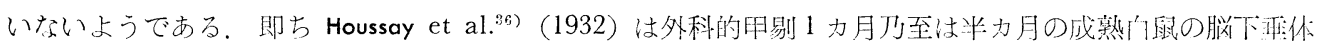




$$
\text { 日本内分泌学会雑誌 }
$$

を海犋に注射し，その甲状腺重量を測定した結果，刘照群のそれにくらべて，その重量は有意の増加を認め なかつた。このととより外科的甲剔後の脳下垂体には向甲状腺作用はみられないと結論し，又 Hohlweg \& Junkman $^{37)}$ (1933) は同様な実験在行ない，その甲状腺の組織学的所見よりみて Houssay と同じ結論在述べ

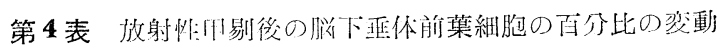

\begin{tabular}{|c|c|c|c|c|}
\hline 鱼 群 & 攃梞潘 号 & 好酸件:紼胞％ & 圾境基性絊胞\% & 色素嫌性紐胞\% \\
\hline \multirow{6}{*}{$\begin{array}{l}\text { 正 } \\
\text { 符 } \\
\text { 刘 } \\
\text { 监 } \\
\text { 槛 }\end{array}$} & A. .277 & 34.6 & 9.7 & 56.8 \\
\hline & A. 278 & 39.3 & 9.1 & 54.1 \\
\hline & A. .279 & 41.7 & 7.9 & 52.2 \\
\hline & A. 280 & 36.2 & 11.7 & 50.7 \\
\hline & A. 157 & 40.8 & 8.3 & 57.2 \\
\hline & 平均值 & $38.5 \pm 1.51$ & $9.3 \pm 0.74$ & $54.2 \pm 1.41$ \\
\hline \multirow{6}{*}{$\begin{array}{c}1] \\
\text { 㔀 } \\
7 \\
11 \\
11 \\
110\end{array}$} & A. .254 & 30.7 & 15.7 & 50.2 \\
\hline & A .255 & 32.9 & 19.7 & 48.4 \\
\hline & A. 289 & 27.9 & 12.6 & 59.8 \\
\hline & A. 290 & 26.0 & 22.7 & 48.6 \\
\hline & A. 178 & 31.5 & 16.9 & 56.2 \\
\hline & 平均推 & $29.8+1.40$ & $17.5+1.95$ & $52.6 \pm 2.55$ \\
\hline \multirow{4}{*}{$\begin{array}{l}\text { 所 } \\
\text { 剔 } \\
14 \\
11 \\
\text { 俳 }\end{array}$} & A. 282 & 19.8 & 37.1 & 46.0 \\
\hline & A. 283 & 20.2 & 32.2 & 54.0 \\
\hline & G.283 & 15.6 & 33.4 & 49.3 \\
\hline & 平均值 & $18.5 \pm 1.79$ & $34.2 \pm 1.85$ & $49.7 \pm 4.01$ \\
\hline \multirow{4}{*}{$\begin{array}{l}\text { 用 } \\
\text { 剔 } \\
30 \\
\text { 日 } \\
\text { 㗏 }\end{array}$} & A. .256 & 1.2 & 48.5 & 49.3 \\
\hline & A. 257 & 2.2 & 51.3 & 46.5 \\
\hline & G.257 & 5.0 & 43.4 & 51.6 \\
\hline & 平均值 & $2.8 \pm 1.33$ & $48.0+3.24$ & $49.1 \pm 1.80$ \\
\hline \multirow{4}{*}{$\begin{array}{l}11 \\
\text { 質 } \\
45 \\
11 \\
110\end{array}$} & A. 208 & 1.0 & 52.0 & 46.9 \\
\hline & A. 209 & 0.8 & 59.7 & 39.5 \\
\hline & G.209 & 1.2 & 48.7 & 50.1 \\
\hline & 平均值 & $1.0 \pm 0.15$ & $53.4 \pm 3.98$ & $45.5 \pm 3.84$ \\
\hline \multirow{4}{*}{$\begin{array}{l}11 \\
\text { 剔 } \\
60 \\
11 \\
\text { 非 }\end{array}$} & A. .258 & 0 & 51.6 & 48.4 \\
\hline & A. .259 & 0 & 49.4 & 50.6 \\
\hline & A. 260 & 0 & 56.8 & 43.2 \\
\hline & 平均值 & 0 & $52.6 \pm 2.68$ & $47.4+2.51$ \\
\hline \multirow{4}{*}{$\begin{array}{c}\prod 1 \\
\text { 剔 } \\
120 \\
17 \\
\text { 排 }\end{array}$} & A. 222 & 0 & 57.0 & 43.0 \\
\hline & A. 251 & 0 & 53.8 & 46.2 \\
\hline & A. 252 & 0 & 59.0 & 41.0 \\
\hline & 平均值 & 0 & $5.6 \pm 1.85$ & $43.4 \pm 1.85$ \\
\hline
\end{tabular}

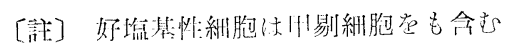


ている. Turner \& Cupps $^{26)}$ (1940) らあ雄白 鼠につき，外科的甲剔後の脳下垂体 TSH 含 有量を測定し，甲剔後40日目では対照群にく らべて $46 \%$ ，甲剔後 6 力月目では50\%の減少 率を， lgel $\mathrm{l}^{38}$ ) (1955) は雄白鼠を外科的に用 剔し，3，6，9，12日後に脳下垂体内 TSH 作用物質を海犋試験で検定した結果，正常無 処置群のものでは甲状腺刺㦸性をもつている のに反し，甲剔群では何等の甲状腺刺㦸作用 物質を認めなかつたと報告している。
第 5 表 放射性甲剔後の Gomori 陽性細胞百分比

\begin{tabular}{|c|c|c|c|}
\hline & 動物数 & Gomori 陽性紐胞\% \\
\hline \multicolumn{2}{|c|}{ 正常無処置群 } & 6 & $2.2 \pm 0.31$ \\
\hline 甲剔 & 7日 & 5 & $0.5 \pm 0.17$ \\
\hline 11 & 14日 & 5 & $6.2 \pm 0.71$ \\
\hline 11 & 30 日 & 5 & $12.9 \pm 1.63$ \\
\hline 11 & 45日 & 4 & $17.7 \pm 1.83$ \\
\hline " & 60 日 & 4 & $21.0 \pm 0.99$ \\
\hline "1 & 120日 & 6 & $27.4 \pm 4.24$ \\
\hline
\end{tabular}

第 6 表 放射性甲剔後の脳下垂体前葉細胞所見

\begin{tabular}{|c|c|c|c|c|c|c|c|c|}
\hline \multicolumn{2}{|c|}{ 甲剔日数 } & 対 照 & 7 & 14 & 30 & 45 & 60 & 120 \\
\hline \multirow{5}{*}{$\begin{array}{l}\text { 好 } \\
\text { 酸 } \\
\text { 性 } \\
\text { 細 } \\
\text { 胞 }\end{array}$} & 細 胞 数 & HH & H & + & \pm & $\pm \sim-$ & - & - \\
\hline & 顆 粒 量 & H & + & $+\sim \pm$ & \pm & $\pm \sim-$ & - & - \\
\hline & 大きさ & + & + & + & $+\sim \pm$ & $+\sim \pm$ & - & - \\
\hline & Golgi 陰影 & - & - & - & - & - & - & - \\
\hline & 核 & 明 & 明 & 明 & $\begin{array}{l}\text { 核濃縮した } \\
\text { のの増加 }\end{array}$ & 同 前 & - & - \\
\hline \multirow{8}{*}{$\begin{array}{l}\text { 好 } \\
\text { 塩 } \\
\text { 基 } \\
\text { 性 } \\
\text { 細 } \\
\text { 胞 }\end{array}$} & 細 胞 数 & + & H & Ht & 册 & Ht & H & HWH \\
\hline & 顆 粒 量 & + & $\pm \sim H$ & $\pm \sim+$ & $(H) ※$ & $(t+1)$ & (HI) & (HI) \\
\hline & 大 き さ & $t \sim H$ & $H$ & Ht & H & HH & H & $H \sim H H$ \\
\hline & Golgi 陰影 & - & \pm & \pm & + & H & H & H \\
\hline & 核 & 明 & 肥 大 & 同 前 & 同 前 & 同 前 & 同 前 & 同 前 \\
\hline & 胞 & - & - & + & H & HH & HII & HIH \\
\hline & 硝子様物質 & - & - & + & H & Ht & HH & HA \\
\hline & 有糸核分裂 & - & \pm & \pm & $\pm \sim-$ & $\pm \sim-$ & $\pm \sim-$ & $\pm \sim-$ \\
\hline \multirow{2}{*}{$\begin{array}{l}\text { 色性 } \\
\text { 素練 } \\
\text { 堆胞 }\end{array}$} & 紐 胞 数 & HW & HH & HW & HWH & 判 & 擞 & $H M^{2}$ \\
\hline & 核 & 明 & 明 & 明 & 明 & 明 & 明 & 明 \\
\hline
\end{tabular}

但し※（括弧）内は $\mathrm{T}$ 顆粒も含む

一方 Chen \& Van Dyke (1934, $\left.\left.{ }^{39}\right) 1936^{25)}\right)$ は外科的甲剔堆雄成熟家鬼の脳下垂体 TSH 含有量を Rowland Parkers 法 ${ }^{40)}$ (1934) で測定し，甲剔 3 カ月以上経過したあのに著しい TSH の増加をみたと報告し， Zeckwer $(1936)^{41)}$ は成熟白鼠を用いて同様な実験を行ない，甲剔時の脳下垂体 TSH は増量していること が結論されたと述べ又，Turner \& Cupps $^{26)}$ (1940) らあ䧳白鼠に外科的甲剔を行ない，Bergman Turner ${ }^{42)}$ 氏 江省用いて脳下垂体 TSH を測定した結果，甲剔40日目のあのでは対照群にくらべて46\%の増加率を得た 之報告している。，又，D'Angelo一派の Gordon et al. ${ }^{27)}$ (1945) は蝌蚪の変態観察法を用いて，外科的用剔 6 力月を経過した成熟雄白鼠の脳下垂体 TSH は対照群にくらべて有意の増加がみとめられたと報じている。

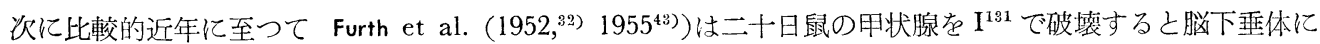
色素㴍性細胞より成る移植可能の腫瘍が癷生するが，乙の腫煬を甲状腺剔出二十日鼠に歴代移植を行なうと， 三代目より正常二十日鼠に移植してむ甲状腺の顕著な肥大が見られることから腫瘍組織中には大量の TSH

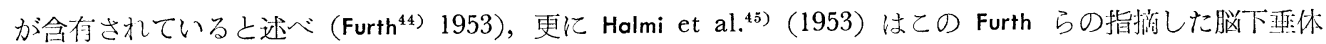

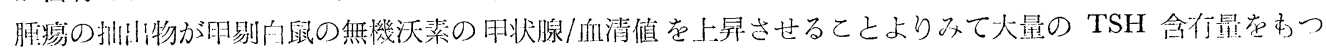


ものであると述べている.

以上述べた如く甲剔後の脳下垂体 TSH 含有量の変動については先進諸家の戊績がなお区及であることが わかる，その山つて来る原因として諸種の要約が考えられるが，先ず甲剔方法として技術的に困難性のある こと, 又, 適確な TSH 量の測定方法のなかつたととなどがその主要因子と考えられる。しかし，放射性甲 剔は従来行なわ机て来た外科的甲剔にくらべて種々な点に於て優れてわり ${ }^{30)}$ ，他方 TSH 測定法も初生觹甲 状腺の $\mathrm{P}^{32}$ 掑取能を示標上する TSH 測定法が簡便且つ優秀なす方法であることが報告されている ${ }^{20)}$. これ らの方法を用いて行つた私の実験成績では放射性甲剔後のTSH 含有量は甲剔 7 日後に於いて，や〉減少が みられるが，14日後では有意の増加を示し，それ以降日数を経るに従い增加の傾向は著しく，甲剔後60日 目及び120日目に於て最も高い含有量を示した，この様な二相性の变化を来たす理由を考えてみるに剔直 後から血清 TSH レベルは速やかに上昇するということ ${ }^{4647)(8)}$ 及び教室の三好が行つた笑験中組織学的にみ て放射性甲剔初期の甲状腺は TSH を投与した甲状腺之同様な所見を呈すると云うとと ${ }^{30}$ ，更に私の観察し た脳下垂体前葉の組織化学的所見，即ち放射性甲剔後7日目に於て Gomori 陽性顆粒の 減少している事加 ら，甲剔の初期に於ては脳下垂体から血中への TSH 放出機能が産生機能よりも盛んなため，TSH か测溜

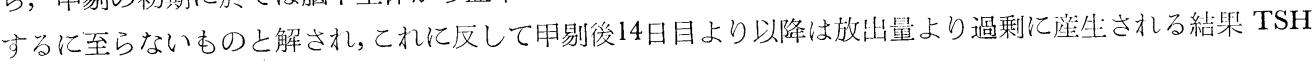
含有量が高值となるすのと推定される。

\section{(3) 脳下垂体前葉の組織学的所見}

i) 好酸性細胞须て

甲剔時に於ては本細胞の減少するととを報告したものが多い。Mac Callum \& Fabyon ${ }^{49)}$ (1907)，Wegelin ${ }^{50)}$ (1925), Zeckwer ${ }^{6)}$ (1935), Marime et al. ${ }^{\text {11) }}$ (1935) Purves ${ }^{52)}$ (1947), Halmi ${ }^{24)}$ (1952), Gumbreck ${ }^{28)}$ (1957),

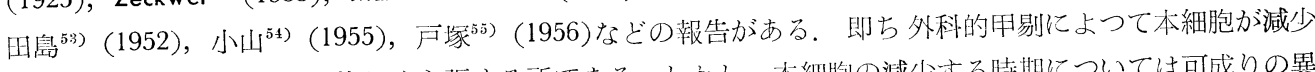
するととは多くの研究者の均しく主掁する所である。しかし，木細胞の減少する時期については可成りの異 論のある所であり早期より消失，減少すると報ずるもの，或いは甲剔後相当の期間を経たのちにほら゙完全に 消失すると述べる者があり，例えば，Knigge ${ }^{\text {(6) }}$ (1958) は白鼠外科的甲剔後 7 日目に好酸性細胞の完全な消 失を, Gumbreck ${ }^{28)}$ (1957) 屯雄白鼠甲剔後10日目に有意の減少を認め, 穴の後20日30日と更に減少し，3力 月目に於てな㨷か汇認められるとと去報告しているが，私の実験成績では好酸性細胞は放射性甲剔後 7 日 目に正常対照群の80\%に減少し，14日目で約50\%に，30日目で10\%に減少し，60日目では完全に消失するこ 之を認めた。一方萎縮ないしは退化した好酸性細胞は放射性甲剔後 $14 ， 30 ４ 5$ 日と日を追つて著明に出現す る。

乙れと同様な知見は Farquher \& Rinehart ${ }^{57}$ ) (1954) 屯外科的甲剔白鼠仗外ける電子顕微鏡的検索によつ て確認し，本細胞は著明な顆粒消失を示し，胞体中には不規則な endoplasmic reticulum や mitochondria が認められ，原形質の退化，萎縮を来すあのが多いと報じている。乙の様な好酸性細胞の減少，消失の機序 は甲剔によつて生ずる体淮中の thyroxine の欠乏が本細胞に 鋭敏な反応をあたらし，ての結果好酸性細胞 は脱顆粒を起こすためであると考えるのが妥当であらう。

ii）好塩基性細胞について

本細胞は甲剔によつて最も著明な変化を来た卞細胞とされ Hohlweg \& Junkman ${ }^{\text {"7 }}$ ) (1933). Severinghaus et al. $\left.{ }^{58}\right)$ (1934), Zeckwer ${ }^{6)}$ (1935), Halmi ${ }^{59)}$ (1950), Purves \& Griesbach $^{(39)}$ (1951), Grumbreck ${ }^{27)}$ (1957),

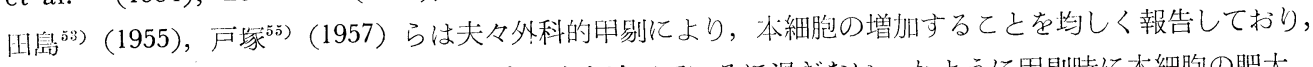
僅かに Schultze (10) $^{(1914)}$ のみが減少を来たすと述べているに過ぎない，かように用剔時に本細胞の肥大， 增加することは多数の研究者の認める所であるが，その増加発現する時期について必らずしあその意見は一 致していない. 即ち Severinghous et al. .5s)（1934）は闸剔後 7 日目以内にすでに好塩基性細胞の增加が明ら

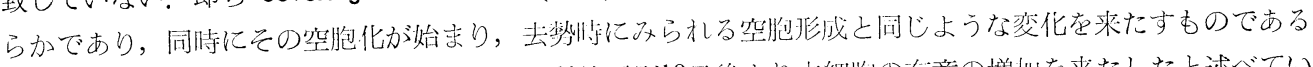

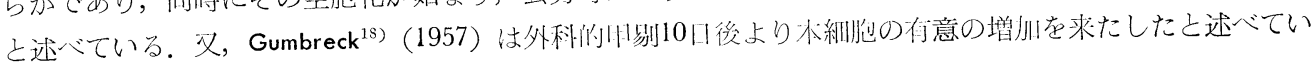
る. 


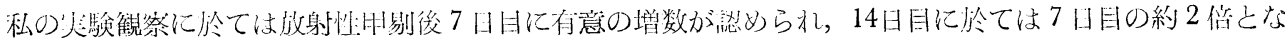

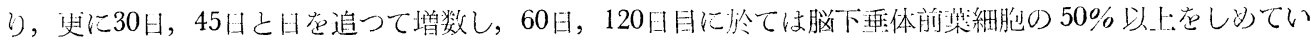

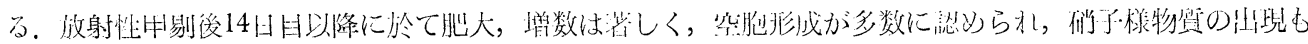
みられた。

iii）色紧嫌怆細胞について

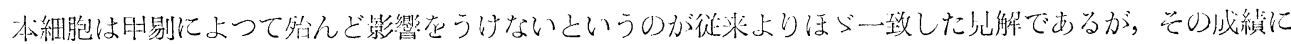
ついては多少の異論がある。即ち Hohlweg \& Junkman ${ }^{377}$ (1933), Severinghaus et al..$^{58)}$ (1934), Zeckwer ${ }^{6}$ )

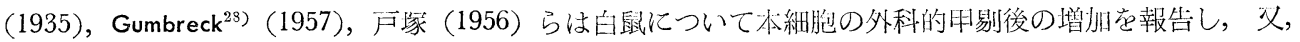

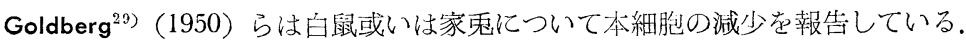

私の実験成緽では放射性甲剔後 7 日目に於て僅かながら減少を示し，甲剔後14日目より概ね各期に於て，

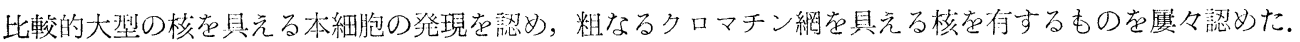



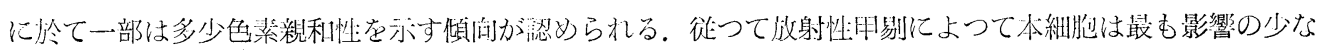
かつたことから，色素媒沚細胞はTSH 分泌之は無関係であるといえる。

iv）甲剔細胞について

甲剔後の脳下垂体前葉の最も特異的な変化として，原形質の肥大，空胞，胞体の colloid の充湍という特 徵をむつた細胞の出現であり，この細胞を甲剔細胞（thyroidectomy cell）と呼ばれている。ささて甲剔細胞 の起源については，古くは色素鋠性細胞の変化したもの或いは好酸性細胞の一変型と見るすのあ多いが，最 も有力視されているのは好塩基性細胞説である. 又, 近年組織化学の進歩により, 好嚗基性細胞が機能的に 異つたもののあるととが指摘され ${ }^{61) 62)}$ ，Halmi ${ }^{66)}$ (1950) は aldehyde fuchsin 染色を用いて，てれらの細胞 を二つに分類した，父，Purves \& Griesbach ${ }^{63) 64) 65)}$ 引は糖蛋白を検出する Periodic acid Schiff 氏染色又忘

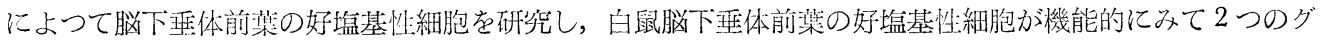
プールに分けられると発表した。 その一つはPAS 染色によつ著しく染色され，前述した如く，腺の周过部 に多く存在する阿形または卵円形の細胞であり，gonadotrophin 分泌と関連するととより， gonadotrophs 之名付け，他の一つは腺の中央部に存在する多角形の細胞で TSH 分泌之関連しているととより thyrotrophs と名づけている，前者は性腺剔出時にみられる去勢細胞の源であり，後者は甲剔に出現する甲剔細胞の起源 であると述べている，私の行つた研究に於ても，放射性甲剔後14日目以降に好塩基性細胞が増加，肥大し， 微細空胞の出現，Gomori 陽性顆粒の增加が放られ，甲剔後30日目以降，原形質の肥大，硝子样物質の增加 は著明となり，小空胞は癒合して大空胞が形成され，乙れらの特徴をむつた細胞が集団的に出現することは

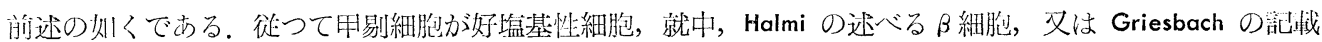

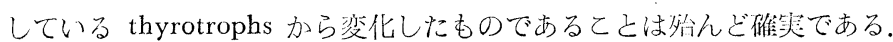

次に Gomori 陽性:顆粓の意義について Purves \& Griesbach ${ }^{10)}$ (1956) らは Gomori 陽性頖粒は TSH の

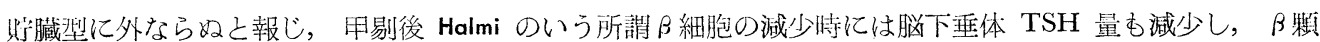
粒とTSH 含有量との間に並行関係があるとしている。乙れそ反し Furth ${ }^{32)}$ (1952)， Bates ${ }^{34)}$ (1957) らは

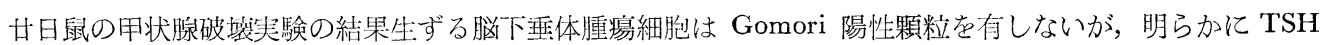

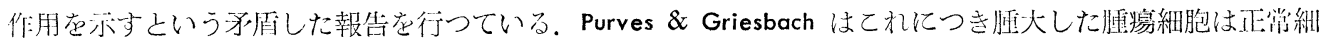

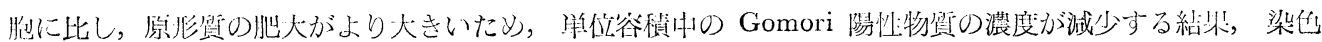

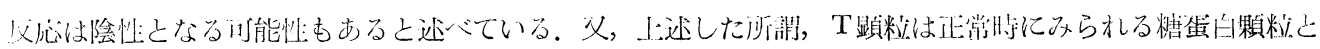

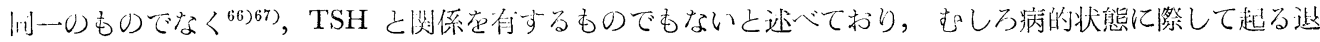
化現象であろうとしている ${ }^{10}$ ．然しながら，私の研究に於ては Gomori 陽性顆䊉湴びに放射性甲剔時にみ

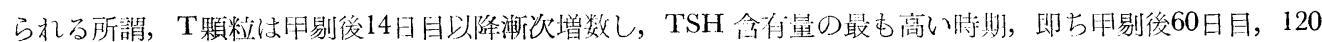

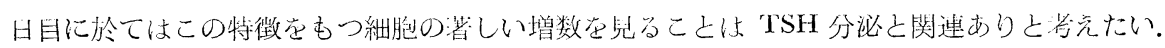

以上諸家の知見や私の組織学的所罗を TSH 含有量の動きと関連して眺劣之き, Gomori 陽性顆粒並び 
にT顆粘はTSH そのもの，或いはそのすべてを表示するものであるとはり光ないにしても TSH 分泌之 衙接な関連を有することは容易に推定される。

\section{第 5 節 結び}

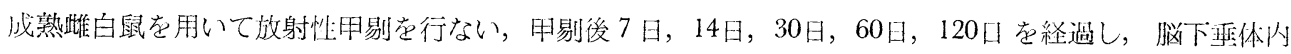
TSH に及ぼす影響を定量的並びに組織化学的に観察して, 次の如き絬果を得た。

（1）放射性甲剔後脳下垂体重量は７日目以降に於て有意の增加がみらえた。白の後14日目以降は徐々に增

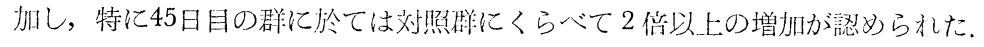

（2）脸下垂体 TSH 含有量は放射性用剔後7日目に於ては対照群にくらべてや〉減少がみられた。しか し，放射性甲剔後14日目に於ては逆に增㞦がられ，目剔後30日，45日群は更に增加し，120日群に最も高

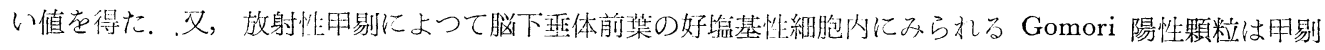
後 7 日目に減少を珰めたが，14日目以降は增加し，30日，45日目頃より甲剔細胞の著しい增数がみら机た。

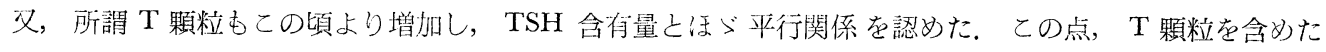
Gomori 陽性顆粒はTSH そのものでなくとあ TSH 様作用物赑として極めて大きな意義を哊するもので あると考えられる。

（3）放射性甲剔により好酸性細泡は脱顆䊉及び色䋕難染性を来たし，甲剔後 7 日目頃より有意の減少がみ



（4）好塩基性細胞は放射性甲剔後一般に增加の傾问を示す，又，脱顆粒を示し，本剔後30日目頃上り原形 留に小空胞を認め，乙れら法娜次大空胞に移行し，甲剔細狍の特徽をむつ細胞が多数出現する。

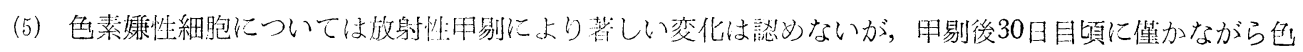

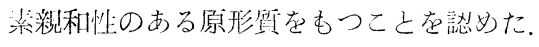

\section{第 2 章 性機能異常時の脳下垂体内 TSH に関する研究}

\section{第 1 節 まえがき}

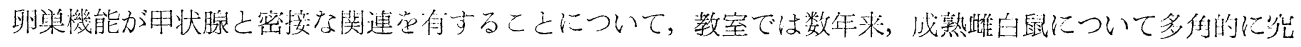


による倹索成䋶から去勢後14日目より甲状腺機能の低下を認》， estrogen がその主役を演じていると述べて いる。文，松本 ${ }^{71}$ は Biskind 氏手術を行つた雌白鼠を用いて甲状腺之笹腺との機能的関係を追求し，TSH と gonadotropin は火火独站して変動する之報している。

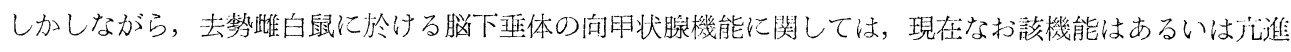
し，あるいは著変なしとし，あるいはむしろ低下している之云う如く，今日な掟説はない，

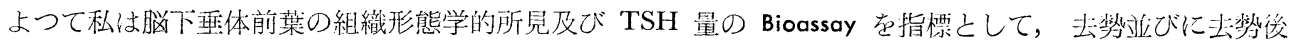
各種性ステロイド投与時に於ける成熟雌白鼠の脳下垂体向妇状脉機能を検索した。

\section{第 2 節 実験動物並びに実験方法}

笑験動物並びに動物飼学管理は第 1 鄣に記述した如くである。性腺剔 江汒洨:卵紧を脂肪組織之共に剔出 し，その手術日を去熬符１日とし， 专染後14日目, 21日目, 28日目の 3 㷙に分け又, 去勢後14日目より各種 の性ステロイドホルモンを第7表に 表示与る様任通続 5 日間投与し投与 終了後 24 時間目に壀殺した。層殺方 江，脸下垂体剔比方法，TSH 測定

第7表 各種入テロイドホルモン投与嶨

\begin{tabular}{|c|c|c|c|c|c|}
\hline 各 & $x=$ & 群 & Steroid hormone & 1 日投与鼍 & 投与全星 \\
\hline & 1 & 群 & estradiol benzoate & $0.5 \gamma$ & $2.5 \gamma$ \\
\hline 第 & 2 & 群 & estradiol benzoate & $200 \gamma$ & $1000 \gamma$ \\
\hline 第 & 3 & 群 & progesterone & $500 \gamma$ & $2.5 \mathrm{mg}$ \\
\hline 筷 & 4 & 燿 & testosterone propionate & $5 \mathrm{mg}$ & $25 \mathrm{mg}$ \\
\hline \multirow{2}{*}{\multicolumn{2}{|c|}{ 筙 5}} & \multirow[t]{2}{*}{ 梆 } & $\{$ estradiol benzoate & $0.5 \gamma$ & $2.5 \gamma$ \\
\hline & & & progesterone & $500 \gamma$ & $2.5 \mathrm{mg}$ \\
\hline
\end{tabular}

第 36 巻 符 12 岇 


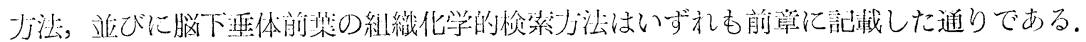

\section{第 3 節 実験成績}

\section{(A) 去勢群}

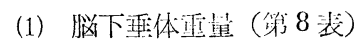

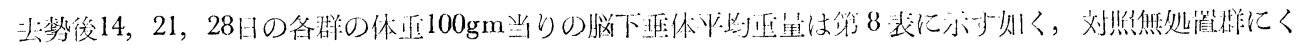

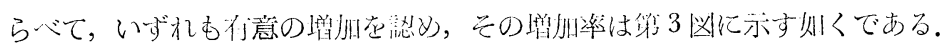

第 8 表 去勢後, 休重並びに悩下画体重量

\begin{tabular}{|c|c|c|c|c|}
\hline 童赘甘数 & 動物数 & $\begin{array}{r}\text { 憵殺時体重 } \\
\text { (mg) }\end{array}$ & 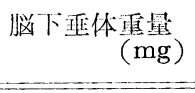 & $\begin{array}{c}\text { 脳下重体重点 mg } \\
\text { 体重100mg } \\
\end{array}$ \\
\hline 玨常無処置群 & 6 & 153.1 & 5.1 & 3.4 \\
\hline $14 \amalg$ & 5 & 137.4 & 6.0 & 4.3 \\
\hline 211 & 6 & 180.3 & 7.7 & 4.4 \\
\hline 2811 & 5 & 157.0 & 7.1 & 4.5 \\
\hline
\end{tabular}

(2) 脳下五体 TSH 食行星○推移 畉坚剔山在行つた成熟䧳白鼠の脳下垂体 $\mathrm{TSH}$ 含有量は術後日数の経過亡其に漸次娍 少する。即ち第 4 図に示す如く単位重童当り の TSH 含有量は著しく減少し，正常舆处 监群のそれにくらべて去勢後14日，21日，28 口湖は刘照相の66.4\%，43.8\%，28.8\%であ る。

(3) 組織学的所兒

i）去勢後14日目，吅形好塩基性細胞の增 数，把大が特徵的で，特に周过部好塩基性細 胞方著しく肥大し， $\beta$ 顆粒はその大きさと密 度を增加している。本顆精は Azan 染色， PAS 染色により可染されるが，Gomori 氏 区岕は陰性である。核は腫大し，一般に偏㒋 に位鄙することが多く，明らかな Golgi 陰 影を認めるものが多い. しかし，空胞の形成

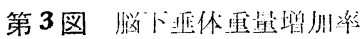

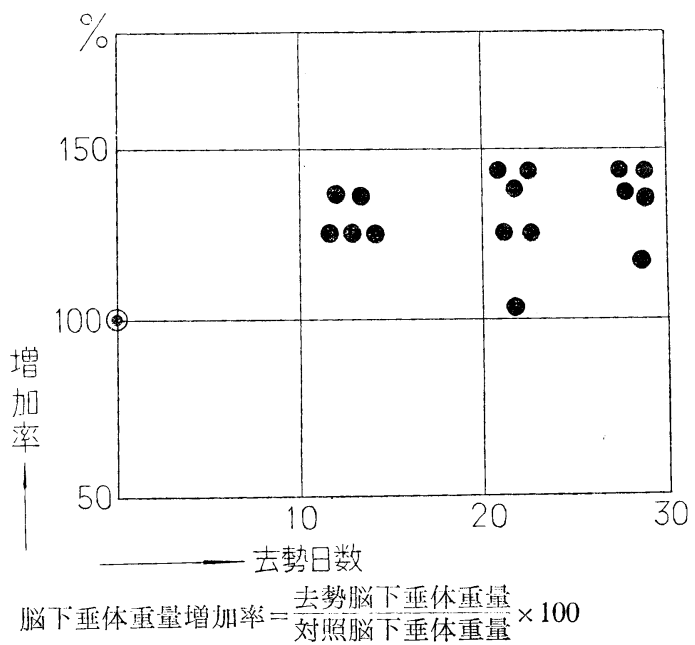

○実験群 @対照群 は未だこの時期に於てはみられない，本細胞は甲剔時に肥大，増数する好湓基性細胞にくらべて顆粒は一般 に密でしかも濃染し，細胞境界む鮮明である。乙のため甲剔時のそれとは明らかに識別可能である。一方，



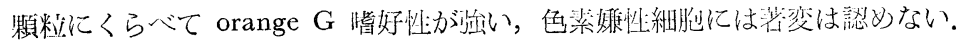

ii）去萟後21日目

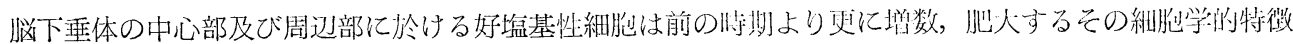
は前期とほメ゙同様であるが，一方，好酸性細胞は術後14日月に比し，や〉增数の傾同がみられたが有意の差

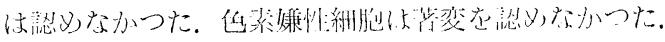

iii）去势後28日目

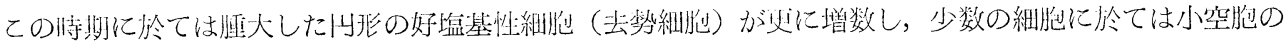


第 4 図 去势後の脳下垂体 TSH 量の変動

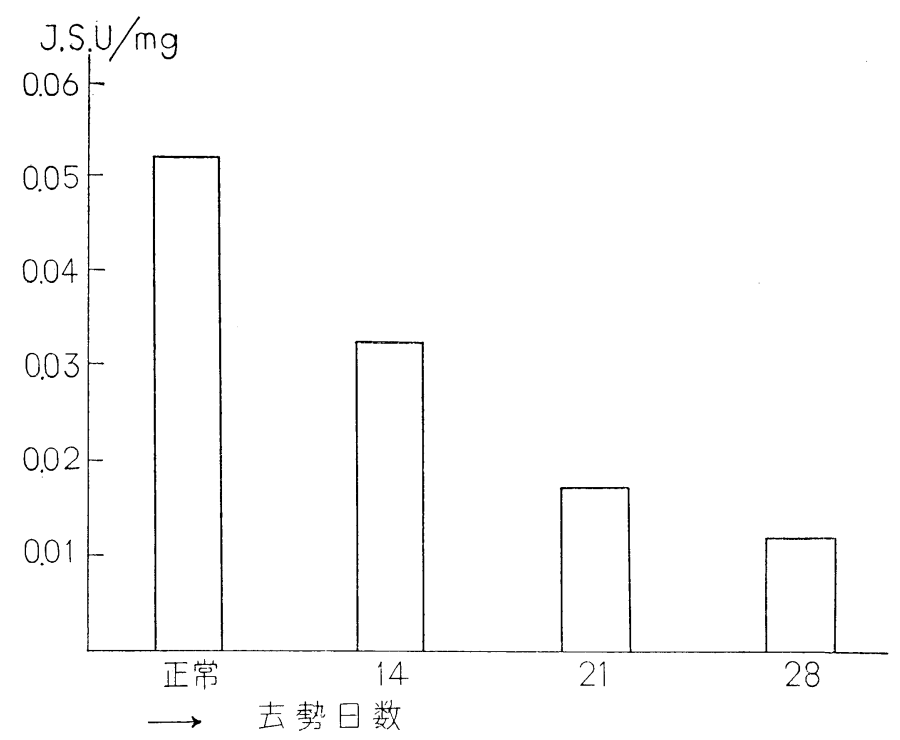

形成や核の濃縮がみられる桹になる，好酸性細胞の百分比は前期にくらべて，や〉減少の傾问をみたが，存 意の差はない. Gomori 陽性細胞は更に減少の傾向在認めた。

以上去樊時に於ける前葉細胞の百分比は第 9 表に示す如くである.

第 9 表 去勢後脳下垂体前葉細胞の百分比

\begin{tabular}{|c|c|c|c|c|}
\hline & 標本番号 & 好酸性細胞\% & 好塩基性細胞\% & 色素嫌性細胞\% \\
\hline \multirow{4}{*}{ 正常無処置群 } & 277 & 34.6 & 8.4 & 56.8 \\
\hline & 278 & 39.3 & 6.4 & 54.1 \\
\hline & 279 & 41.7 & 6.5 & 51.7 \\
\hline & 平均值 & $38.5 \pm 2.00$ & $7.1 \pm 0.79$ & $54.2 \pm 1.80$ \\
\hline \multirow{4}{*}{ 去勢後14日 } & 112 & 41.9 & 10.8 & 47.1 \\
\hline & 114 & 34.3 & 12.6 & 53.0 \\
\hline & 115 & 21.4 & 18.1 & 60.3 \\
\hline & 平均值 & $32.5 \pm 7.56$ & $13.8 \pm 2.68$ & $53.4 \pm 4.66$ \\
\hline \multirow{4}{*}{ 去勢後21日 } & 284 & 40.8 & 11.1 & 48.3 \\
\hline & 285 & 31.1 & 20.9 & 47.9 \\
\hline & 286 & 31.7 & 14.2 & 53.8 \\
\hline & 平均值 & $34.5 \pm 3.81$ & $15.4 \pm 3.53$ & $50.0 \pm 2.75$ \\
\hline \multirow{4}{*}{ 去勢後28日 } & 287 & 40.1 & 18.3 & 41.4 \\
\hline & 288 & 34.3 & 15.5 & 50.1 \\
\hline & 236 & 25.7 & 30.6 & 43.5 \\
\hline & 平均值 & $33.3 \pm 5.09$ & $21.4 \pm 5.05$ & $45.0 \pm 3.18$ \\
\hline
\end{tabular}

[註] 好塩基性細胞は去勢細胞も含む 
（B）去勢後各種性ステロイド投与群

(1) 脳下垂体重量（第10表）

去勢後14日目より各種性ステロイドを連続 5 日間投与した各々の脳下重体重量は第10表に示す如くで，い

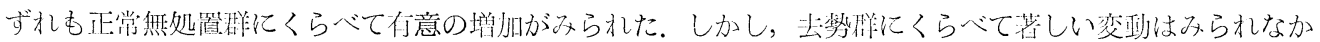

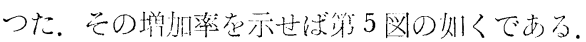

（2）敛下垂体 TSH 全们量の变化

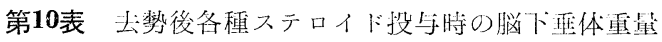

\begin{tabular}{|c|c|c|c|c|c|}
\hline 各群 & $\begin{array}{l}\text { ステロイド } \\
\text { 投与全量 }\end{array}$ & 動物数 & $\begin{array}{r}\text { 磻殺時体重 } \\
\text { (mg) }\end{array}$ & $\begin{array}{r}\text { 脳下重体重量 } \\
(\mathrm{mg})\end{array}$ & $\frac{\text { 脳下重体重量 }}{\text { 体重100mg }}$ \\
\hline 讴常無処置群 & & 6 & 153.1 & 5.1 & 3.4 \\
\hline 対照群（业勢後14日） & & 5 & 137.4 & 6.0 & 4.3 \\
\hline estradiol benzoate & $2.5 \gamma$ & 4 & 141.0 & 6.1 & 4.3 \\
\hline estradiol benzoate & $1 \mathrm{mg}$ & 4 & 136.0 & 7.2 & 5.3 \\
\hline progesterone & $2.5 \mathrm{mg}$ & 4 & 125.0 & 5.1 & 4.2 \\
\hline testosterone propionate & $2.5 \mathrm{mg}$ & 4 & 142.5 & 7.4 & 4.6 \\
\hline$\left\{\begin{array}{l}\text { estradiol benzoate } \\
\text { progesterone }\end{array}\right.$ & $\left\{\begin{array}{r}2.5 \gamma \\
2.5 \mathrm{mg}\end{array}\right.$ & 6 & 125.0 & 4.9 & 3.9 \\
\hline
\end{tabular}



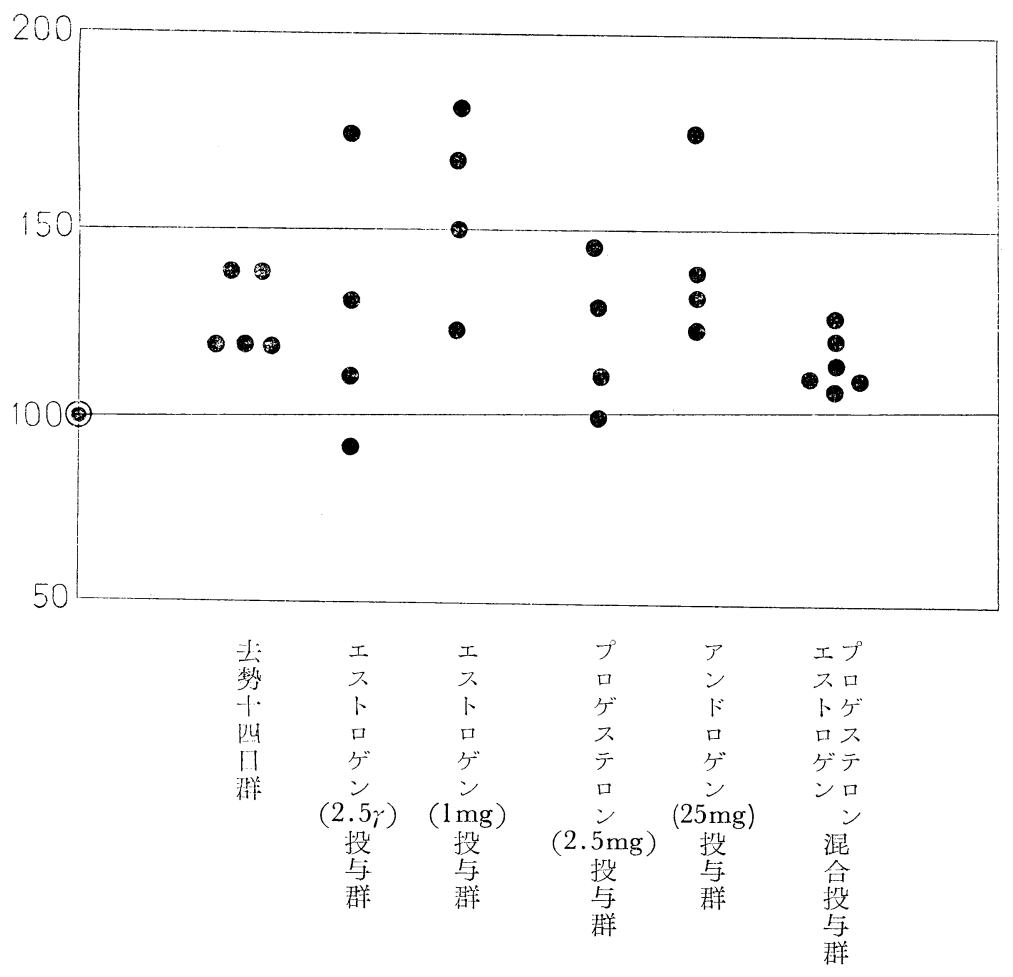

○実験群—刘照群 
去樊後14日目より各種の性ステロイドを投与した祭の脳下垂体TSH 含有量の変化は符11表に示す如くで ある. 即ち estradiol benzoate 1 日 $0.5 \gamma$ 及び $200 \gamma ， 5$ 日間連続投与した両群では共に去勢無処置群にく らべて有意に增加し，その含有量は夫々 $196.9 \%, 181.8 \%$ であつた.

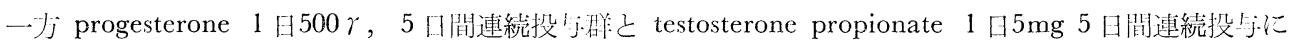

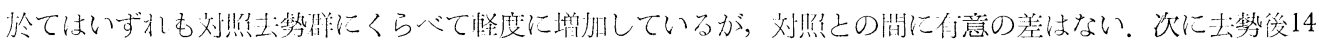

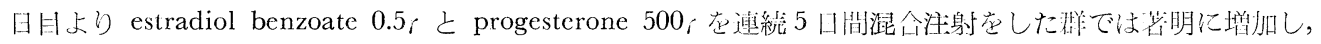
その合有宣は190.9\%で夘論有意差がある。

第11表 去熦後各種性ステロイド投与時の脳下垂体 TSH 量

\begin{tabular}{|c|c|c|c|c|}
\hline 各 & $\begin{array}{l}\text { ステロイド } \\
\text { 投与全量 }\end{array}$ & 動物数 & $\begin{array}{c}\text { 脳下重体重量 } \mathrm{mg} \\
\text { 体重 } 100 \mathrm{mg}\end{array}$ & $\begin{array}{c}\text { TSH 量 J.S.U. } \\
\text { 脳下金体重量 mg }\end{array}$ \\
\hline 立勎のみ & & 5 & 6.0 & 0.033 \\
\hline estradiol benzoate & $2.5 \gamma$ & 4 & 6.1 & 0.065 \\
\hline estradiol benzoate & $1 \mathrm{mg}$ & 4 & 7.2 & 0.060 \\
\hline progesterone & $2.5 \mathrm{mg}$ & 4 & 5.1 & 0.047 \\
\hline testosterone propionate & $2.5 \mathrm{mg}$ & 4 & 7.4 & 0.045 \\
\hline$\left\{\begin{array}{l}\text { estradiol benzoate } \\
\text { progesterone }\end{array}\right.$ & $\left\{\begin{array}{r}2.5 \gamma \\
2.5 \mathrm{mg}\end{array}\right.$ & 6 & 4.9 & 0.063 \\
\hline
\end{tabular}

(3) 組織学的听見

i) estradiol benzoate 投志林

estradiol benzoate 1 日 $0.5 \gamma$ を 5 日間連続投与した群の組織所見は去勢後 14 日目群と然んど大美なく， 脳下垂体前葉細胞百分比に於ては好酸性細胞の僅かの増加がみられ，好塩基性細胞の僅かな減少がみられた が有意の変化はなかつた。一方 estradiol benzoate 200; 灰2 日間連続投与した群に於ては好垭基性細胞の 減少がみられ，明らかに去勢細胞の出現が抑制されており，又，色素嫌性細胞並びに好酸性細胞は去勢群に くらべて，いずれも增加している. Gomori 陽性細胞も僅かに增加の傾向がみられた.

ii) progesterone 投与群

好塩基性細胞の百分比は去勢後21日目の場合に相似している。即ち去勢後14日目のものより更にその数が 増加し，特に毛細管周辺部に著しい。一方好酸性細胞，色素嫊性細胞には著变をみとめ得なかつた。即ち progesterone は estrogen に比し脳下垂体に於ける去勢変化の阻止作用が微弱である.

iii) testosterone propionate 投与群

好酸性細胞がや〉增加した注か，好篮基性細胞，色素轵性細胞は著変をみなかつた。

iv) estradiol benzoate 並びに progesterone 混合投与群



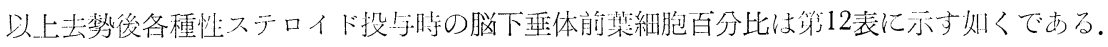

\section{第 4 節 総括並びに考按}

\section{（1）去勢群}



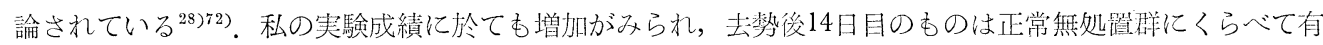
意の増加を示し，去勢後日数の増加と共に徐々な増加が衿められる。乙れらの増加は好壏基性細胞の肥大， 増数に起因するあのと考光られる。

次に卵樂剔出による脳下垂体 TSH 含有量の变化に関する從来の交献をみると Igel ${ }^{39}$ (1955)，は外科的 第36巻 第 12 昂 
第12表 去勢14日後各種性ステロイド投与時の脳下垂体前葉細胞の百分比

\begin{tabular}{|c|c|c|c|c|}
\hline 群 & 標本番号 & 好酸性細胞 & $\begin{array}{r}\text { 好塩基性細胞 } \\
\%\end{array}$ & 色素嫌性細胞 \\
\hline \multirow{4}{*}{ 去泶のみ } & 241 & 41.2 & 13.6 & 45.2 \\
\hline & 242 & 35.6 & 16.9 & 47.5 \\
\hline & 243 & 30.2 & 12.9 & 52.8 \\
\hline & 平均值 & $35.6 \pm 3.88$ & $14.4 \pm 1.48$ & $48.5 \pm 2.73$ \\
\hline \multirow{4}{*}{$\begin{array}{c}\text { 去熦 }+ \\
\text { estradiol benzoate } \\
0.5 \gamma \times 5\end{array}$} & E 3 & 35.5 & 13.9 & 50.5 \\
\hline & E 4 & 39.1 & 13.7 & 47.1 \\
\hline & E 5 & 34.8 & 13.8 & 51.2 \\
\hline & 平均值 & $36.4 \pm 1.62$ & $13.8 \pm 0.07$ & $49.9 \pm 1.57$ \\
\hline \multirow{4}{*}{$\begin{array}{c}\text { 去勢 }+ \\
\text { estradiol benzoate } \\
200 \gamma \times 5\end{array}$} & A 268 & 39.9 & 8.9 & 51.0 \\
\hline & A 269 & 42.7 & 7.1 & 50.0 \\
\hline & A 270 & 37.1 & 12.3 & 50.6 \\
\hline & 平均值 & $39.9 \pm 1.98$ & $9.4 \pm 1.86$ & $50.5 \pm 0.35$ \\
\hline \multirow{4}{*}{$\begin{array}{c}\stackrel{\text { 去勢 }+}{\text { progesterone }} \\
\qquad 500 \gamma \times 5\end{array}$} & P 2 & 34.4 & 15.8 & 49.6 \\
\hline & P 3 & 26.8 & 20.2 & 42.9 \\
\hline & P 4 & 38.6 & 9.8 & 51.5 \\
\hline & 平均值 & $33.2 \pm 3.29$ & $15.2 \pm 3.72$ & $48.0 \pm 3.18$ \\
\hline \multirow{4}{*}{$\begin{array}{c}\text { 去勢 }+ \\
\text { testosterone } \\
\text { propionate } \\
5 \mathrm{mg} \times 5\end{array}$} & A 275 & 33.9 & 12.0 & 54.0 \\
\hline & A 276 & 38.8 & 14.9 & 46.2 \\
\hline & A 277 & 36.9 & 16.8 & 46.7 \\
\hline & 平均値 & $36.5 \pm 1.74$ & $14.5 \pm 1.71$ & $48.9 \pm 3.08$ \\
\hline \multirow{4}{*}{$\begin{array}{c}\text { 去勢 }+ \\
\text { estradiol benzoate } \\
0.5 \gamma \times 5 \\
\text { progesterone } \\
500 \gamma \times 5\end{array}$} & E P 1 & 32.7 & 11.8 & 55.4 \\
\hline & E P 2 & 36.5 & 15.4 & 48.0 \\
\hline & E P 3 & 38.8 & 12.8 & 48.3 \\
\hline & 平均值 & $36.0 \pm 2.17$ & $13.3 \pm 1.30$ & $50.5 \pm 2.95$ \\
\hline
\end{tabular}

甲剔並びに卵巣剔出を同時に施行し，雄白鼠脳下垂体 TSH 量の変化を観察したととろ，無影響であつた之 云い，続いて先ず甲剔を行ない，その後二週間後に去勢を行つて14日後に脳下垂体の TSH 量を検索した之 ころ，何等の影響も認めなかつたという結論を述べている。, 又, Pratt $^{74}$ (1943), Thompson ${ }^{75}$ ) (1943) らむ 二十日鼠を用いて，雄では去勢後 $2 ， 3 ， 4$ 週間経過した後では脳下垂体 TSH の変化がみられず，雌では 去勢後 1,3 週間で著変を来たさないが, 4 乃至 5 週間後では僅かに減少をみたとしている.最述 Contopoulos $(1958)^{76}$ も甲状腺剔出後，去勢を行つた雄白鼠は単に甲剔をのみ行つた場合にくらべて脳下垂体 TSH は何 等変化をもたらさない之報告している。

以上の成績は性腺の剔出により，脳下垂体 TSH が有意の変化を認めないとする報告であるが，又

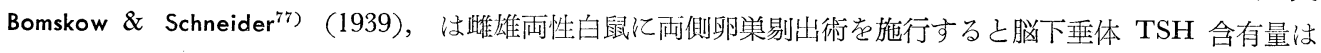
正常生理的範囲内ではあるが, 軽微な增量がみられると述べている。乙れらの知見は前章で述べた如く, 甲 状腺の形態学的所見より間接に脳下垂体 TSH 産生能を推定したものに過ぎない.

一方, Hoskins ${ }^{78}$ （1941）は去勢により脳下垂体 TSH 量は減少を来たし，甲状腺機能は低下すると発表し 
た. 又, Bates, Riddle \& Lahr ${ }^{79}$ (1935) らあ去勢して雄牛の脳下垂体 TSH は成熟雄牛の約半分量である 之報告し，Reece \& Turner $^{80)}$ (1937) らも生後4１0力月の雄牛脳下垂体 TSH 量は38.36海猽単位 (G.P.U.) にくらべて去勢雄牛脳下垂体のそれは 25.5G.P.U. と減少し, 生後11 23力月の雄牛脳下垂体は35.02G.P.U. であるが，去勢により 16.30G.P.U. と更に減少すると述べ，更に Turner \& $\operatorname{Cupps}^{26)}(1940)$ らは成熟雌白 鼠を用いて実験を行ない，去勢後20日目の前菻 TSH 量は対照群のそれにくらべて18\%の減少を示し，雄白 鼠に於ては同様の実験により，44.4\%の減少をみたよのべ，又，圭勢後66月目の雌白鼠では零となり，焳に 㹞ては $82.7 \%$ の減少をみたと報告している。

私の行つた成熟䧳白鼠の去勢䒠験では脳下垂体 TSH は去勢後14日目で刘照玡にくらべて有意の減少を来 たし，との後日数を経るに従い，更に減少を来たした。この事象の解翻は性ステロイド投与時の項に於て一 括して述へる。

次に卵紧剔出時の脳下垂体前葉の組織学的所見は Fichera ${ }^{81)}$ (1905), 以来，幾多の研究者たちによつて報 告されている ${ }^{7273)}$. Trautman ${ }^{82)}$ (1909)，Kolde ${ }^{83)}$ (1912)，Brauer ${ }^{84)}$ (1929) Stein ${ }^{85)}$ (1933) は去勢後好酸性 細細の増数を報じ，一厅，Biedl ${ }^{86)}$ (1913), Schleidt ${ }^{87}$ (1914) らは僅少ながら減少するとし, Gyer \& Claus ${ }^{85}$ (1937), Kirkmann ${ }^{89)}$ (1937) Halmi ${ }^{59}$ (1950), らは何等变化を認め得ないと述べている.

私の去勢実験に於ては術後14日目に好酸性細胞の軽度の減少が認められた。その後，日を追つてや〉増㞦 の傾向を示した。しかし，去勢後28日群は対照群にくらべてや〉低い值を示していた．乙の点 Addison ${ }^{9 n}$ (1916), その先進諸家の白鼠の実験成績之類似していた.

又，去勢時好塩基性細胞については肥大，増数が著しいとするものが多く，Nelson \& Gallaghar (1935) ${ }^{91)}$ Smith \& Severinghaus ${ }^{92)}$ (1933), Schooly ${ }^{94)}$ (1938)などの報告がある.

しかし，これらの報告者は thyrotrophs と gonadotrophs の機能形態学的な分類法の提案以前の報告で あり，私の研究に於ては去勢時に現われる去勢細胞は，PAS 反応は陽性であり Gomori 氏反応は陰性であ る所謂 gonadotrophs に由来することは明らかである。色素糨性細胞は去勢により殆んど影響をうけないと いうのが従来よりのほぶ一致した見解である。私の実験例では去勢後14日目にや〉減少し，その後徐々に減 少がみられた。一般に本細胞は色素溗性，即ち不染性で，細胞境界あ不明瞭であるが，去勢後28日目で一部 に多少の色素親和性を示す傾向がみられた. 又, 去勢時に起こる thyrotrophs の形態学的变化についての知 見は甚だそしいが，今回の実験により去勢によつて，Gomori 顆粒の減少傾向が認められた，乙の点組織学 的方法によつて TSH 活性度の多寡を論ずることが出来えないが，その Gomori 顆粒を有する細胞の減少 していることと私の行つた TSH 含有量測定の成績とは一致する.

(2) 去勢後各種性ステロイド投与群

Steroid hormone の投与によつて TSH 産生能に及ぼす变化に就き観察した研究は少なく，しかもこの すべてが唯, 形態学的変化の追求に終つている.

estrogen 投与に依つて生ずる向甲状腺ホルモン産生細胞の形態学的変化に就き Severinghaus (1939) ${ }^{95}$ ), Nelson ${ }^{96)}$ (1942)，は外科的甲剔後に 発生する甲剔細胞は estrogen 投与により抑制されたと述心，石原 ${ }^{97}$

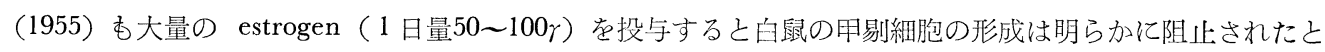
報している. 又，山本 ${ }^{48}$ (1958) は正常白鼠に estrogen を投与すると，短期注射群では甲状腺は組織学的 に機能低下像を示し，脳下表体は各種前葉細胞数並びに形態の特異的变化をみないが，12１8週という長期 投尔在行なうと，甲状腺の機能九進所胃之脳下垂体前葉の好塩基性細胞に肥大，その顆粓の減少，微小空胞 の!l現など明らかな thyrotrophs の機能过進を示す所見を胃たと述べている。

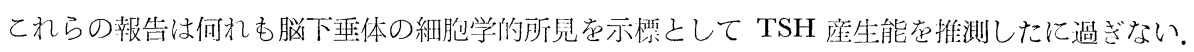


教室の山口 ${ }^{68)}$ ，井上 ${ }^{69}$ らは去勢白国の时状腺機能は各種 steroid hormone の中 estrogen のみが优進的に 俳用することを確浔している。

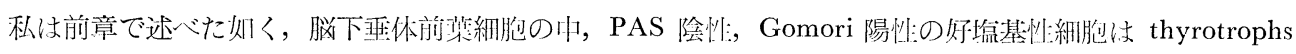
第36巻 第 12 夏 
である点から考觉て，私の実験成績に於て，少量の estradiol benzoate 投与磁に贬ては有意の好塩基性細 胞の怔きは認め難いか， $1 \mathrm{mg}$ 投与碚に於ては明らかな去勢細胞の形成阻止と Gomori 陽性細胞の增加を認

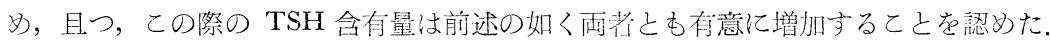

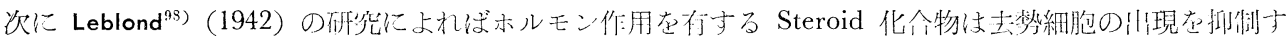

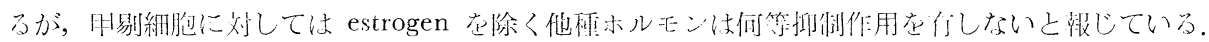

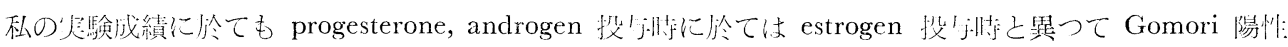

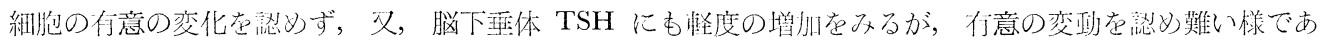
る.

又， estrogen と progesterone の混命投与㭙について述べると私の用いた混介摔，即ち estrogen : proge-

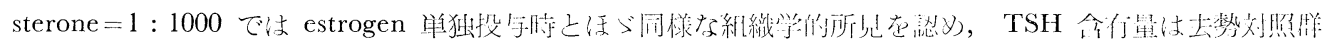
のそれにくらべて有意の增加を示している。

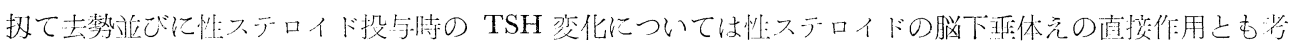

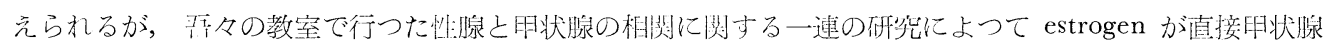

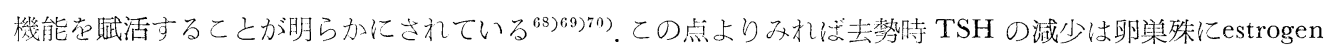
欠乏によつて惹起された甲状腺機能娍退による TSH の需要の低下により，脳下垂体 TSH の座生，分泌の 減弱を来たし，乙れとは反対に estrogen 単独投与报びに estrogen, progesterone 混命投与により直接甲状

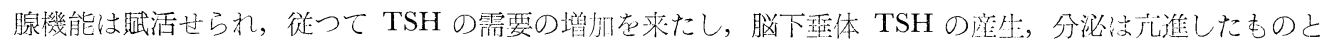
学えられる。

\section{第 5 節 結び}

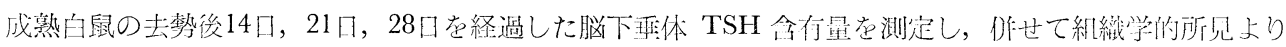

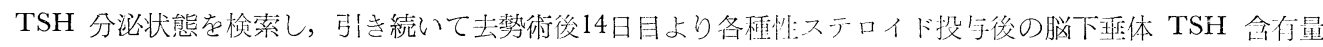
を測定し，併せて組織学的榆索を行ない次の結果を得た。

(1) 去勢により脳下垂体重量は有意の増加が認められた。

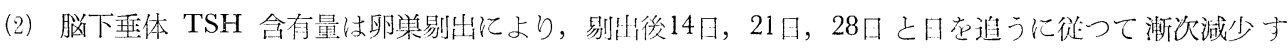
る.

（3）去勢により脳下垂体前蒏の好酸性細胞は時划的に多少の变動がみられた，好塩基性細胞は術後日数の 增加之平行して，增数，肥大がみられ，剔出後 21 日目頃より原形質に宔胞を認め，顆䊀は粗大なすのが多 く, PAS 反応陽性总示す顆粓細胞，所調，去勢細胞の怙現がみられた。乙れに反し Gomori 陽性細胞の減 少がみられた。

（4）去勢後14日目より各種性ステロイド投与を行ない，いずれも脳下垂体重量は正常無処啨群にくらべて 有意の增加がみられた。しかし，去柯群にくらべて何等大差を認めなかつた。

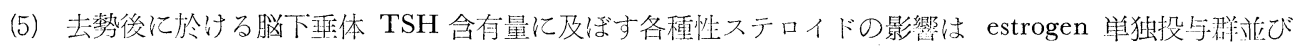


testosterone 投与喟に於ては䖵かの增加を示したが，有意の変化はみられなかつた。


の需要の大小在反咉しているもの之考流る。

\section{全章の総括並びに考按}

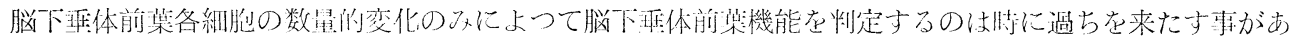
ると云わなけ糸ばならない。

しかし，著者は細胞数の測定に㞦えて，脳下㻎体分泌ホルモン，就币，TSH 量の定量測定を行ない，各

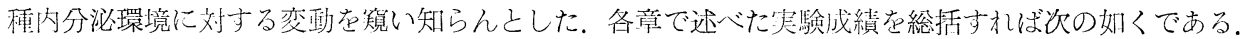

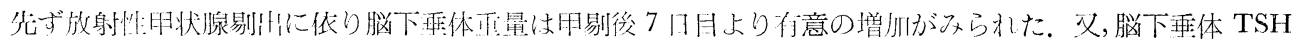


含有量については甲剔後 7 日目では一時的にや〉減少を示したが，しかし，甲剔後14日目より増加の傾向が みられ，甲剔後30日，45日之更に増加し，120日目では最も高値を得た。乙れら実験群の各々脸下垂体前葉 は組織学的には Gomori 陽性細胞は甲剔後30日目頃から著明に増加し，120日目では大きな顆粒となつて認 もられた，同時に所謂T顆䊀の增数が認められた。乙れらの事から Gomori 陽恻顆䊀站びにT顆䊀は TSH

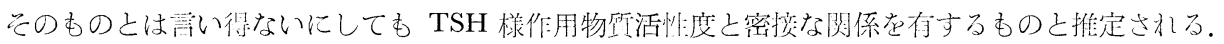

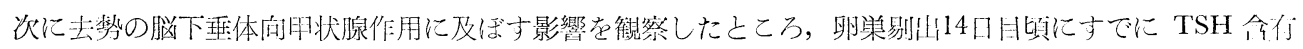
量は有意の減少がみられ，剔出後21日，28日とその傾间は著明に認りられた。なお組織学的所胃については PAS 陽性細胞の増加を認效たが, Gomori 陽性細胞の増加は認め得ずむしら娍少をみた。

又, 去勢後14日を経過したすのに各種性ステロイドを投与し, 脳下垂体 TSH 含有量を検討したところ, estrogen 投与群では脳下垂体 TSH 活性度を高》るのに反し, progesterone, androgen 投与㭙には同様の 傾问は認めるが，有意の变化は認め得なかつた。一般に去萟により甲状腺は機能低下の状態になると云われて

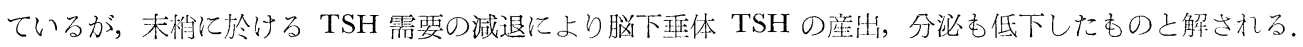
他方去勢時甲状腺機能の低下には卵栄の estrogen 消失がその主因となつているのであるが， estrogen 単独 投与立びに estrogen, progesterone 混命投与により, 甲状腺が䟼活せられ, TSH の需要が高竞り，还つて 脳下垂体 TSH の産生，分泌が元進したものと理解される。

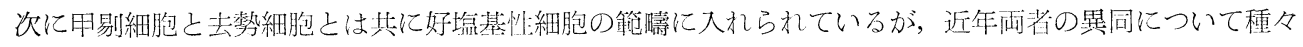

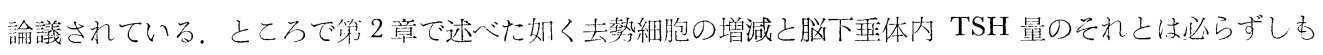
一致しない．又，組織化学的にみても第 1 章及び第 2 章で夫々記載した如き特徽のある点からみて甲剔細胞 と去勢細胞とは判然と区別すべきであると考える。

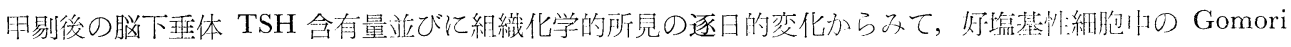
陽性細胞がTSH 分泌值接関与方るすのと見做すのが妥当であろう.

稿を擱える当り, 種々な御助言, 御協力总戴いた林要博士，置塩学士に対し厚く御礼申し上げます。.

(本諭文の要旨は第 5 回日本内分必学会西日本地方会, 符 31 回日本内分泌学会及び第10回口本产枓㷌人科 学会に於て発表した)

\section{文献}

1) Smith, P.E. : Am. J. Anat., $45: 205,1930 . \quad 2)$ Werner, S.C. : The Thyroid, Hoeber-Harper, New York 1957.

3) Keating, F.R. et al. : Endocrinology, $36:$ 137, 1945.

4) Rawson, R.W. and Money, W.L. : Rec. Pro. Horm. Res., $4: 387,1949$.

5) Severinghaus, A.E. : Physiol. Rev., $17: 556,1937$.

6) Zeckwer, I.T. et al. : Am. J. Med. Science, $190: 145,1935$.

Griesbach, W.E. : Brit. J. Exp. Path., 22 : 245, 1941.

8) Loeser, A. : Klin. Wschr., $13: 766,1934$.

9) Loeser, A. : Klin. Wschr., 14 : 4, 1935.

10) Purves, H.D. \& Griesbach, E.W.: J. Endocrin., 13 :

365, 1956.

11) Ueda, Y. et al. : Kobe J. Med. Sciense, $4: 51,1958$.

12) Niépce, B.:

Traité du goiter et du cretinisme, Paris, 1851, 42) 上り引周

13) Rogowitsch, N. : Beitr. Path. Anat., $4: 453,1889$. 14) Griesbach, W.E. et al. : Brit. J. Exp. Path., $22: 249,1941$. MaC Kenzie, C.G. \& Mac Kenzie, J.B. : Endocrinology, 32 : 185, 1943.

16) Astwood, E.B. et al. : Endocrinology, $32: 210,1943$.

17) Levey, H.A. \& Solomon, D.H. : Endocrinology, $60: 118,1957$.

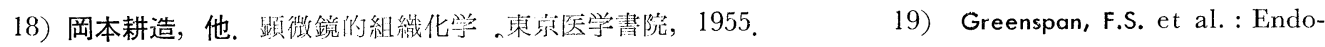
crinology, $58: 767,1956$.

20）置塩觙三他：川本内分泌学会誌，33：126，1957.

21) Wilson, W.D. \& Erzin, C. : Am. J. Path., $30:$ 891, 1954.

22) Rasmussen, A.T. \& Herrick, R. : Proc. Soc.

Exp. Med., $19: 416,1922$.

Endocrinology, $50: 140,1952$.
23）井上哲夫：内科宝函，3:908，1956.

25) Chen, C. \& Van Dyke, H.B. : Chenese J. Physiol., 10:285, 第36卷 箓 12 号 
1936.

26) Turner, C.W. \& Cupps, P.T. : Endocrinology, $26: 1042,1940$.

27) Goldon, A.S.

et al. : Endocrinology, $36: 53,1945$.

28) Gumbreck, L.G. : Am. J. Anat., 101:321, 1957.

29) Goldberg, R.C. \& Chaikoff, I.L. : Endocrinology, $46: 91,1950$.

30）三好俊之：産婦人科進歩,

$10: 1,1958 . \quad 31)$ Furth, E.J. \& Burnett, W.T. Jr. : Proc. Soc. Exp. Biol. Med., $78: 222,1951$.

32) Furth, E.J. et al. : Proc. Soc. Exp. Biol. Med., $80: 4,1952$.

33) Bates, R.W. et al. : Proc

Soc. Exp. Biol. Med., 93 : 525, 1956.

34) Bates, R.W. et al. : Endocrinology, 61:549, 1957.

35) Adams, A.E. : Quarterly Review of Biology, 21 : 1, 1946.

36) Houssay, B.A. et al. : Compt. rend. Soc. Biol., 111 : 830, 1932.

37) Hohlweg, W. \& Junkman, K. : Arch. Ges. Physiol., 232 : 148, 1933.

38) Igel, H. : Acta endocrinologica, $18: 455,1955$.

39) Chen, G. \& Van

Dyke, H.B. : Proc. Soc. Exp. Biol. Med., $32: 484,1934$.

40) Rowlands, I.W. \& Parkeres, A.S. :

Biochem. J. $28: 1829,1934$

41) Zeckwer, I.T. : Am. J. Physiology, $117: 518,1936$.

Bergman, A.J. \& Turner, C.W. : Endocrinology, $24: 656,1939 . \quad 43)$ Furth, E.J. et al. : J. Clin. Endocrinology, $15: 81,1955 . \quad$ 44) Furth, E.J. et al. : Cancer Research, $13: 298,1953$.

Halmi, N.S. et al. : Endocrinology, 52 : 19, 1953.

46) Van Dyke, D.C. et al. : Anat. Record, 106 : 292, 1950.

47) Contopoulos, A.N. : Endocrinology, $62: 642,1958$.

48) 山本隆信 : 日本 内分泌学会誌，33:870, 1958

49) MaC Collum, W.G. \& Fabyan, M. : Bull. Johns Hopkins Hos., $18: 341 ， 1907 ， 5)$ より引用

50) Weglin, G. : Virchow's Arch. 254 : 689, 1925.

Marine, D. et al. : Proc. Soc. Exp. Biol. Med., 32 : 803, 1935.

52) Purves, H.D. \& Griesbach, W.E. : Brit. J. Exp. Path., 27 : 170, 1947.

54）小山良彦他：第28回日本薬理学会総会発表，1955.

53) 田島 洋：日本病理学会誌，44:449，1955.

55) 戸塚孝一郎：東京慈恵会医科大学雑誌,

73 : 1091, 1957.

56) Knigge, K.M. : Anat. Record, 130 : 543, 1958.

57) Farquher, M.G.

\& Rinehart, J.F. : Endocrinology, $55: 857,1954 . \quad 58)$ Severinghaus, A.E. et al. : Proc. Soc. Exp. Biol. Med., $34: 1127,1934 . \quad 59)$ Halmi, N.S. : Endocrinology, $47: 289,1950$

60) Schultze, W.H. : Virchow's Arch., $216: 443,1914$.

61) Zeckwer, I.T. : Am. J. Path. $13: 985,1937$. 62) Zeckwer, I.T. : Am. J. Path., $14:$ 773, 1938.

63) Purves, H.D. \& Griesbach, E.W. : Endocrino$\log$, $49: 244,1951$.

64) Purves, H.D. \& Griesbach, E.W. : Endocrinology, 49 : 427, 1951.

65)

Purves, H.D. \& Griesbach, E.W. : Endocrinology, 49 : 652, 1951.

66) Catchpole, H.D. : J. Endocrinology, $6: 218,1949$.

67) Barnett, R.J. et al. : Endocrinology, 59 : 398, 1956.

68) 山口彦

司：神戸医大紀要，9:170，1957.

69）井上 康：日本内分泌学会誌，35:670，1959

70)

柿沼祐一他：第33回日本内分泌学総会発表, 1960 。

72) 清成要平：日本内分泌学会誌，4:1561，1928.

71）松本隆治 : 神戸医大紀要，15:328，1959.

74) Pratt, M.A. : Honor Paper, Mount Holyoke College, 1943，35）より引用

73) 林 幹夫 : 名古垦医学, $69: 52,1955$.

M.J. : Honor Paper, Mount Holyoke College, 1943, 35) より引用

75) Thompson, Record, 130 : 288, 1958.

77) Bomskow, C. \& Schneider, E. : Arch. Exp. Path. Pharmak., 191 :

715,1939

78) Hoskins, R.G. : Endocrinology, W.W. Norton \& Co., New York 1941, 35) より

引用 79) Bates, R.W. et al. : Am. J. Physiol., $113: 259,1935$.

80) Reece, R.P. \&

Turner, C.W. : Mo. Aq. Exp. Sta. Res. Bul., 266, 1937, 26) より引用

81) Fichera, G. : Arch. Ital. de Biol., 43 : 405，1905. 5) 占可引用

82) Trautman, A. : Arch. mikro. Anat., $74: 311,1909$.

73）ょり引用

83) Kolde, E. : Arch. Gynäk., 98 : 505, 1912.

84) Braver, M. : Z. mikro

anat. Forsch., $16: 101,1929$.

85) Stein, S.J. : Anat. Record, $56:$ 15, 1933.

86) Biedle,

A. : Innere Sekretion, $2: 108 ， 1913.73)$ より引用

87) Schleidt, J. : Zbl. Physiol., $27: 1170$, 1914. 73）より引用

88) Guyer, M.F. \& Clous, P.E. : Anat. Record, $67: 145,1937$.

Kirkmann, H. : Am. J. Anat., $61: 233,1937 . \quad$ 90) Addison, W.H.F. : Anat. Record, $10: 171,1916$. 


$$
\text { 木戸論文附困（その1) }
$$
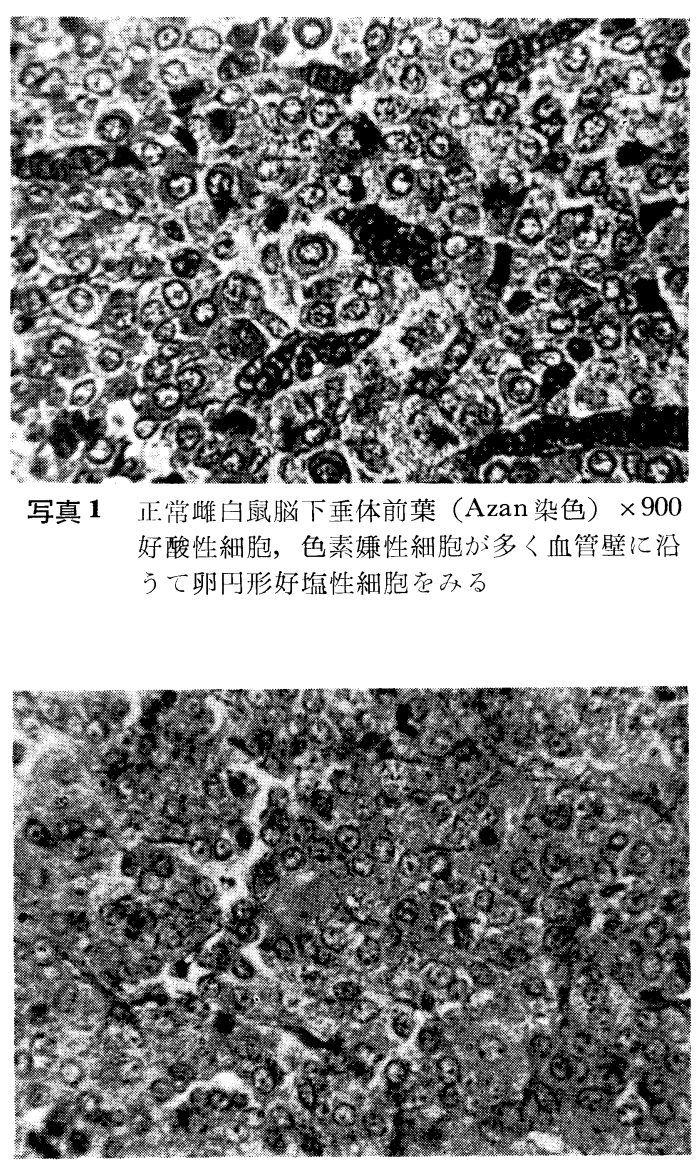

写真 3 甲剔後 30 日目雌白鼠脸下夰体前葉 (PAS 染 色） $\times 800$

好塩基性細胞の肥大，その数の増加をみとめ られる



真写 5 甲剔後60日目雌白鼠脳下垂体前葉 (Gomori 氏染色） $\times 900$

好塩基性細胞の肥大は最も著明で甲剔細胞， T顆粒が誌められる

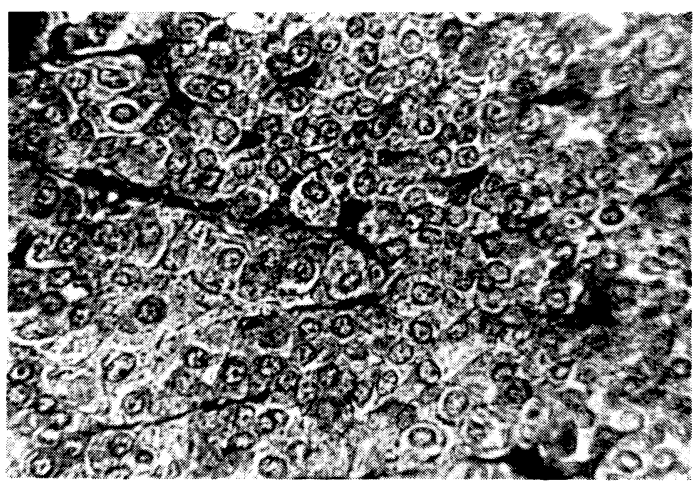

写真 2 甲剔後 7 日目雌白鼠脳下垂体前葉（Azan 染 色） $\times 900$

好酸性細胞の脱顆粒の像がみとめられ，好塩 基性細胞の原形顆粒は増強するのがるられる

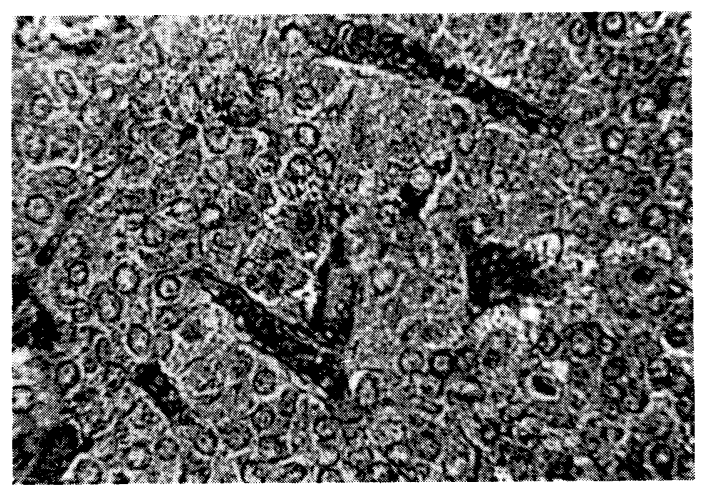

写真 4 性剔後30日目雌白鼠脳下垂体前葉 (Gomori 氏染色） $\times 900$

好酸性細胞は殁んど消失し，好垛基性細胞の 原形質肥大は著しく細胞境界は不明瞭である

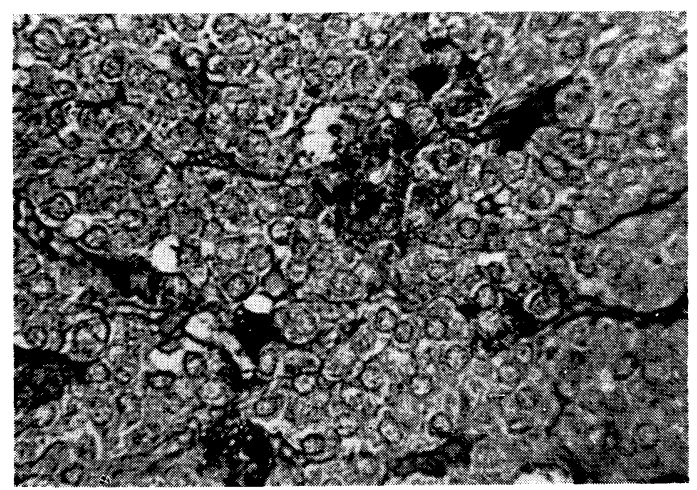

写真 6 甲剔後 120 日目雌白鼠脳下垂体前葉 (Gomori 氏染色） $\times 900$ 好塩基性細胞に空胞形成がみられ，いわゆる $\mathrm{T}$ 顆粒の著明な増加がみられる 


$$
\text { 木戸論交附図（その2) }
$$

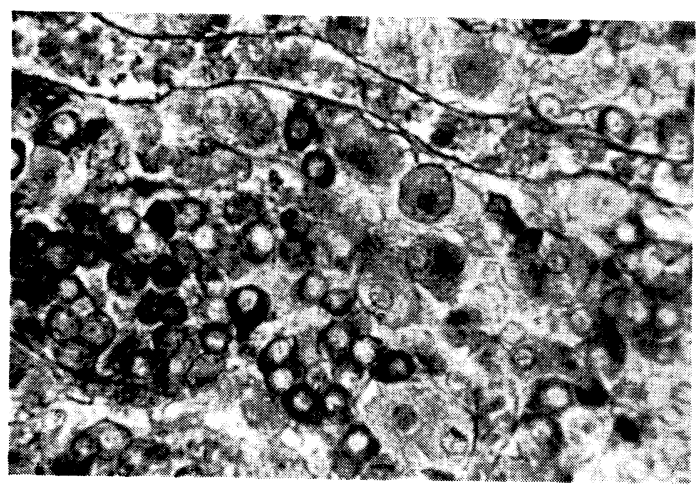

写真 7 去勢後14日目雌白滔脳下乘体前葉 (Azan 染 色) $\times 900$

血管壁に沿つた gonadotrophs は肥大し，核 は周辺部に偏在している。



写真 9 去勢後 estradiol benzoate $(200 \gamma \times 5)$ 投与 雌白鼠脳下乘体前葉 (Azan 染色) $\times 900$ 去勢細胞の出現が抑制されている

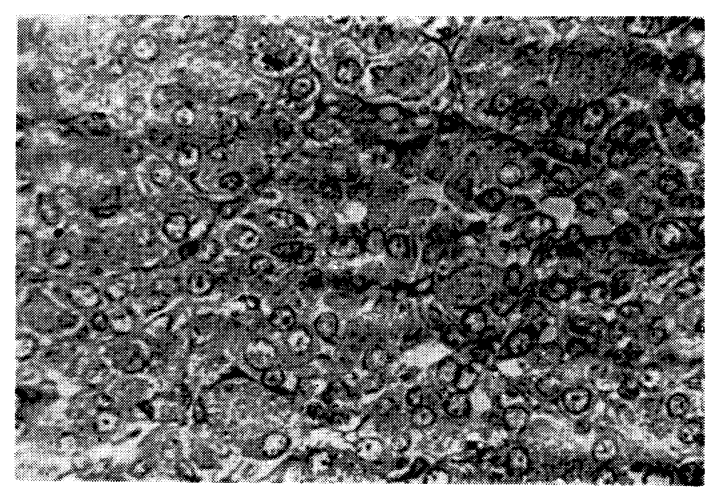

写真 8 去勢後30日目雌白鼠脳下垂体前葉 (PAS 染 色) $\times 900$ 好塩基性䋱胞には PAS 陽性物質が喼められ 空胞形成もみられる

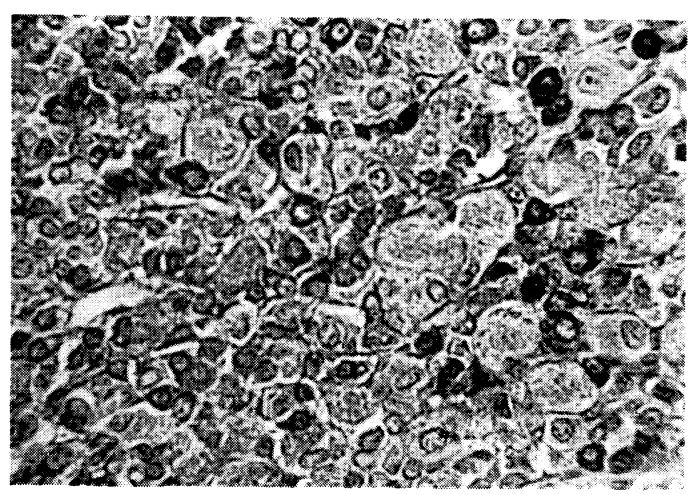

写真10 去勢後 progesterone $(500 \gamma \times 5)$ 投与雌白鼠 脳下乘体前葉 (Azan 染色) $\times 900$ 好塩基性紼胞の肥大がみられ，その核は周辺 部に偏在している

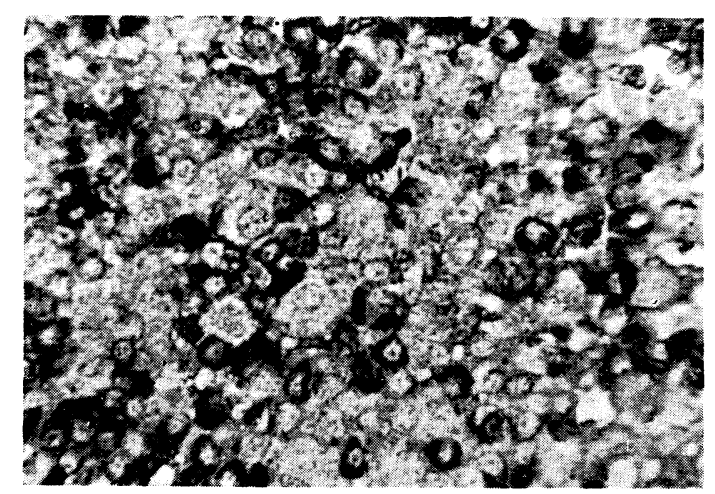

写真11 尖勢後 testosterone propio nate $(5 \mathrm{mg} \times 5)$ 投与雌白鼠脳下乘体前葉 (Azan 染色) $\times 900$ 好塩基性細胞の肥大がみられ，その榜は周辺 部に偏在している 
91) Nelson, W.D. \& Gallagher, T.F. : Anat Record, 74 : 129, 1935.

92) Smith, P.E. et al. : Anat. Record, $57:$ 177, 1933.93$)$ 横倉弘吉 : 医学研究, $23: 126,1953$.

94) Schooly, J.P. \& Riddle, O. : Am. J, Anat., 62 : 313, 1938.

95) Severinghaus, A.E. : Sex and Internal Secretion, The Williams and Wilkins Company, Baltimore, Chap 19., 1045, 1939.

96) Nelson, W.O. :

Federation Proceeding, 1:63, 1942.

97) 石原 力：日本产科婦人科学会雑誌，5:8, 1954 .

98) Leblond, C.P. et al. : Proc. Soc. Exp. Biol. Med., 51 : 159, 1942. 